\title{
Milovan Đilas - polityk, myśliciel, analityk systemu komunistycznego. Cz. 1: Buntownik i komunista
}

Zarys treści: W prezentowanym artykule została przedstawiona ewolucja postawy politycznej, przede wszystkim zaś myśli politycznej Milovana Đilasa w sprawie tzw. nowej klasy i systemu komunistycznego - jego powstania, charakteru i nieuniknionego zaniku. Zwrócono uwagę na poglądy i koncepcje „nowej klasy” w ujęciu jego poprzedników, od Nikołaja Bakunina poczynając. A także na zasadnicze różnice między myślą Đilasa i teoriami Karla Marksa, niezależnie od posługiwania się marksowską (marksistowską) metodą badawczą i terminologią twórcy Kapitału. Artykuł powstał w oparciu głównie o pisma Đilasa, z Nowa klasą na czele, oraz o bardzo bogatą literaturę przedmiotu.

Outline of content: In the article, Michał Jerzy Zacharias presents the evolution of the political stance, and especially the political thought of Milovan Đilas on the so-called 'new class' and the communist system: its origins, character, and inevitable collapse. The author draws attention to the views and concepts of the 'new class' as depicted by his predecessors, starting with Nikolai Bakunin. He also emphasises the fundamental differences between Đilas's thoughts and the theories of Karl Marx, regardless of the use of the Marxian (Marxist) research method and terminology of Das Kapital's author. The article is based mainly on Đilas's writings, especially The New Class, and the subject's wealthy literature.

Słowa kluczowe: Milovan Đilas, Karl Marks, Josif W. Stalin, Josip Broz-Tito, komunizm, Jugosławia, „nowa klasa”, lewicowe odchylenie, sowiecko-jugosłowiański konflikt 1948 r., system samorządowy, partyjna biurokracja polityczna, III Nadzwyczajne Plenum KC ZKJ

Keywords: Milovan Đilas, Karl Marx, Joseph Stalin, Josip Broz Tito, communism, Yugoslavia, 'new class', leftist bias, 1948 Soviet-Yugoslav conflict, local government system, party political bureaucracy, Third Extraordinary Plenum of the Central Committee of the Union of the Communists of Yugoslavia 
Milovan Đilas jest znany przede wszystkim jako autor Nowej klasy - dzieła pierwotnie opublikowanego w Stanach Zjednoczonych w 1957 r. i zawierającego podsumowanie jego przemyśleń dotyczących systemu komunistycznego: jego powstania, charakteru i perspektyw ${ }^{1}$. Niemniej musimy pamiętać, że ten dawny, bliski podwładny i współpracownik Josipa Broza-Tity nie był pierwszą i jedyną osobistością piszącą o degeneracji rewolucji oraz istnieniu warstwy posiadającej własne interesy i zawłaszczającej władzę kosztem całego społeczeństwa. Sam później uważał, że gdy pisał swoją pracę, nie wiedział, że wcześniej już Nikołaj Bucharin, Bertrand Russell i Nikołaj Bierdiajew używali terminu "nowa klasa” na opisywanie tego samego zjawiska, choć na tym polu, jak twierdził, bardziej byli „profetami niż analitykami”'. Komentował, że „to ciekawe, iż takie opinie występowały wcześniej, ale nigdy nie zostały one rozwinięte $\mathrm{w}$ formie całkowitej teorii [...] Kiedy opracowywałem własną teorię i pisałem swoją książkę, nie byłem pod wpływem kogokolwiek". Nowa klasa powstała w rezultacie "tylko mego doświadczenia i moich przemyśleń"3. Mimo tego stwierdzenia pisał jednakże w przedmowie do swego dzieła, że "prawie wszystko, co zawiera ta książka zostało już powiedziane gdzie indziej, ale na inny też sposób" ${ }^{\prime}$. W zgodzie więc $\mathrm{z}$ tą trafną oceną należy pokrótce przedstawić poglądy i oceny poprzedników Đilasa. Mają one długą, dziewiętnastowieczną historię i rzeczywistą wagę gatunkową. Ich prezentacja umożliwi lepsze, pełniejsze zrozumienie problematyki „nowej klasy” w ujęciu Đilasa - jej powstania, charakteru i przyczyn zanikania. W niniejszym artykule zostaną również przedstawione polityczne i teoretyczne przesłanki prowadzące go do tego właśnie ujęcia. Do jego własnego rozumienia systemu komunistycznego, jakże odmiennego od tego, które przedstawiali „klasycy” z Karlem Marksem na czele.

Jeden z badaczy życia i myśli Đilasa, Dragutin Leković pisze, że nie wymieniał on nazwiska Michaiła Bakunina jako jednego z myślicieli piszących o zagrożeniu stwarzanym przez ewentualne rządy „nowej klasy”. Uwaga jest trafna, także $\mathrm{z}$ tego względu, że Bakunin przedstawiał swoje opinie w latach sześćdziesiątych i siedemdziesiątych XIX stulecia, a więc w okresie powstawania i kształtowania międzynarodowego ruchu socjalistycznego i robotniczego. A to właśnie wówczas problem możliwości pojawienia się wspomnianej warstwy był szczególnie

1 M. Djilas, The New Class. An Analysis of the Communist System, New York 1957; wyd. pol.: idem, Nowa klasa wyzyskiwaczy (analiza systemu komunistycznego), Paryż 1957; idem, Nowa klasa. Analiza systemu komunistycznego, Paryż 1957; idem, Nowa klasa. Analiza systemu komunistycznego, tłum. A. Lisowski, Nowy Jork 1958. Korzystałem z tego ostatniego wydania.

2 Idem, Une societé imparfaite. Le communisme désintegré, Paris 1969, s. 22 (wyd. anglojęzyczne: idem, The Unperfect Society. Beyond the New Class, New York 1969).

3 C.L. Sulzberger, Paradise Regained. Memoir of a Rebel, New York-London 1985, s. 135.

${ }^{4}$ M. Dżilas, Nowa klasa..., s. 4.

${ }^{5}$ D. Leković, Milovan Đilas i socijalizam. Filozofsko-istorijska razmatranja, Podgorica 2010, s. 417. 
dostrzegany. Wynikało to $\mathrm{z}$ faktu, że teoretycy, ideolodzy oraz myśliciele socjalistyczni czy też z szeregów anarchistów, jak w przypadku Bakunina, przedstawiali różne wizje przyszłego społeczeństwa i w związku z tym nie mogli pominąć właściwego, $\mathrm{z}$ ich punktu widzenia, systemu władzy, a także zagrożeń, które na tym polu mogły się pojawić.

Bakunin i jego zwolennicy wyrażali typową dla anarchistów opinię, że dopóki będzie istniało państwo, dopóty będzie istniało panowanie, a więc także warstwy uciskane przez władzę. Można sobie wyobrazić sytuację, że proletariat stanie się klasą panującą, ale zawsze będzie to panowanie nad kimś, nad „nowym proletariatem”, np. „kriestianskają czernią”, pospolitym ludem, chłopstwem, „które, jak wiadomo, nie cieszy się sympatią marksistów" nizmu, ponieważ „powoduje (on) pochłonięcie wszelkich sił społecznych przez państwo" i „prowadzi nieuchronnie do centralizacji własności w ramach państwa", zwalczanego przez niego ${ }^{7}$. Rosyjski anarchista był w zasadniczym sporze $\mathrm{z}$ Marksem, uważał go za doktrynera, a w nazwie przedstawianego przez niego "naukowego socjalizmu” dostrzegał dążenie do oddania nauce władzy nad życiem, do podporządkowania "nieuczonych mas” uczonym przywódcom socjalistycznym. Sugerował, że chodzi o zapewnienie uprzywilejowanej pozycji elicie wykształcenia. Marksistowskie państwo niechybnie stałoby się jedynie „aparatem kierującym masami odgórnie, przy pomocy inteligencji, a więc uprzywilejowanej mniejszości”" W sporach na forum I Międzynarodówki Bakunin zarzucał Marksowi zapędy centralistyczne i dyktatorskie, a także reformistyczne kunktatorstwo maskujące faktyczną zdradę rewolucji teorią „obiektywnych praw rozwoju społecznego”. Byłaby ona do przyjęcia przez tzw. arystokrację robotniczą, ale całkowicie sprzeczna $z$ interesami i buntowniczymi nastrojami niewykwalifikowanego "proletariatu nędzy”, żądającego natychmiastowej rewolucji i niemającego nic do stracenia ${ }^{9}$. Bakunin stwierdzał, że postulowany przez twórcę Kapitału system stanie się „zhierarchizowanym i silnie scentralizowanym organizmem, gdzie aparat rządzący skoncentruje $\mathrm{w}$ swych rękach wszystkie siły wytwórcze, tworząc nową, uprzywilejowaną warstwę”. Dodawał, że „socjalizm bez wolności to niewola i brutalność. Wolność bez socjalizmu to system przywilejów i niesprawiedliwości. Tak ukształtowane państwo będzie wyzyskiwać". Wszelkie prawodawstwo, władza i wpływy uprzywilejowanych, „oficjalnych i uprawnionych”, rządzących w wyniku „powszechnego głosowania”, doprowadzą jedynie do tego, że ludzie ci wykorzystają swoje wpływy „na korzyść panującej i wyzyskującej mniejszości, a przeciwko interesom

${ }^{6}$ H. Temkin, Marks i Bakunin w pierwszym Międzynarodowym Stowarzyszeniu Robotników, „Nauki Humanistyczne" 11 (Wrocław 2007), s. 227, 230.

7 J. Guillaume, L'Internationale. Documents et souvenirs (1864-1878), t. 1, Paris 1905, s. 74-75; H. Temkin, op. cit., s. 211, przypis 8.

${ }^{8}$ M. Bakunin, Pisma wybrane, t. 2, Warszawa 1965, s. 197; A. Walicki, Zarys myśli rosyjskiej. Od oświecenia do renesansu religijno-filozoficznego, Kraków 2005, s. 409.

9 M. Bakunin, op. cit., s. 144; A. Walicki, Zarys myśli rosyjskiej..., s. 402-403. 
olbrzymiej, ujarzmionej większości” ${ }^{10}$. W ujęciu Bakunina takie przewidywania wiązały się z krytyką państwa, bowiem każde, nawet najbardziej „republikańskie i demokratyczne, nawet pseudoludowe [...] wymyślone przez pana Marksa, w istocie swej jest niczym innym jak tylko aparatem kierującym masami odgórnie, przy pomocy inteligenckiej, a więc uprzywilejowanej mniejszości, która lepiej jakoby rozumie interesy ludu aniżeli sam lud"11.

Krytyka Marksa występowała także w poglądach polskiego myśliciela Jana Wacława Machajskiego. Na przełomie XIX i XX stulecia potępiał on wszelkie odmiany socjalizmu i złowieszczą, jak głosił, rolę inteligencji. $\mathrm{W}$ tym również przejawiało się jego podobieństwo do rosyjskiego anarchisty. Zdaniem Marshalla S. Shatza Machajski znał prace Bakunina, które stanowiły zasadniczą inspirację dla jego teorii i poglądów ${ }^{12}$. Nie wiemy, czy tak było istotnie ${ }^{13}$, ale podobnie jak Bakunin, autor Pracownika umysłowego rzeczywiście wyrażał przekonanie, że „państwo pana Marksa" stałoby się nową formą wyzysku i zniewolenia. Stanowiłoby to konsekwencję faktu, że wspólnie z burżuazją, a więc posiadaczami kapitału i środków produkcji oraz właścicielami ziemskimi, inteligencja wchodzi w skład, jak pisał, „społeczeństwa burżuazyjnego" pozostającego w antagonistycznych stosunkach z proletariatem. Są one zasadniczymi sprzecznościami występującymi w systemie kapitalistycznym ${ }^{14}$. Podobnie jak burżuazja, inteligencja uczestniczy w wyzysku proletariatu, w zagarnianiu tzw. wartości dodatkowej. W rezultacie postulowana przez Marksa likwidacja prywatnej własności środków produkcji przyniosłaby zniesienie wyłącznie wyzysku kapitalistycznego, wyzysku burżuazji, nie wyzysku w ogóle. Nastąpiłaby swoista dyslokacja kapitału, z rąk prywatnych w społeczne, w praktyce - w ręce „pasożytniczej” inteligencji, zajmującej miejsce dawnej burżuazji. Inteligencja nadal żyłaby z przywłaszczanej wartości dodatkowej i stanowiłaby zasadniczą, w istocie jedyną kadrę zarządzającą gospodarką, społeczeństwem i państwem. Proletariat jak w kapitalizmie otrzymywałby jedynie głodowe płace, „najniezbędniejszą karmę” dla nędznego przeżycia ${ }^{15}$.

${ }^{10}$ M.J. Zacharias, Intelligentsia and the New Class. Political Elites According to Jan Wacław Machajski and Milovan Djilas, „Studia z Dziejów Rosji i Europy Środkowo-Wschodniej” 52 (2017), z. 3, s. 163.

11 M. Bakunin, op. cit., s. 197.

12 M.S. Shatz, Jan Wacław Machajski. A Radical Critic of the Russian Intelligentsia and Socialism, Pittsburgh (Pa.) 1989, s. 37.

${ }^{13} \mathrm{Na}$ podstawie prac Machajskiego należy stwierdzić, że ocena Shatza może być tylko wynikiem przypuszczenia, a nie logicznym wnioskiem wysuwanym po analizie pism polskiego myśliciela.

14 Machajski pisał m.in., że „rewolucja we Francji z 1848 r., a konkretnie wydarzenia czerwcowe, ukazała «sprzeczności kapitalizmu» w głębszy sposób niż Manifest Komunistyczny - nie jako antagonizm między kapitalistami a robotnikami, tylko między burżuazyjnym społeczeństwem a proletariatem”. To nie tyle „burżuazja”, co „stale rosnące burżuazyjne społeczeństwo [podkreślenie - M.J.Z.] jest śmiertelnym wrogiem proletariatu”, J.M. Machajski, Pracownik umysłowy i inne pisma, red. P. Laskowski, Warszawa 2015, s. 190, 194.

15 Ibidem, s. 262-263, 290, 311. 
Rzeczywistość w „Kraju Rad” bezpośrednio po październikowym przewrocie z 1917 r. zdawała się potwierdzać w dużym stopniu przepowiednie polskiego myśliciela. Nie mogła ona umknąć uwadze socjalistycznych teoretyków i polityków. Już Karl Kautsky w 1919 r. używał pojęcia "nowa klasa” w swoich analizach ${ }^{16}$. Zdaniem wybitnego znawcy dziejów Rosji i ZSRS Richarda Pipesa sowieccy przywódcy z samym Włodzimierzem Leninem na czele „denerwowali się” coraz większą biurokratyzacją systemu, który stworzyli. Systemu uginającego się pod ciężarem pasożytniczej warstwy funkcjonariuszy wykorzystujących swoje stanowiska do prywatnych celów i ponadto bardzo mało wydajnych ${ }^{17}$. Jak pisał Adolf Joffe do Lwa Trockiego, „od góry do dołu wszędzie to samo. Na najniższym szczeblu jest to para butów i gimnastiorka; wyżej samochód, wagon kolejowy, salon Sownarkomu, mieszkania na Kremlu albo w hotelu National; a na najwyższych szczeblach, gdzie to wszystko jest dostępne, prestiż, eksponowana pozycja i sława"18.

Głębsze przyczyny powyższej sytuacji starał się przedstawić w ogólnych, teoretycznych rozważaniach Bucharin. W pierwszych latach po przechwyceniu władzy przez bolszewików wyrażał przekonanie, że w rezultacie dotychczasowego, edukacyjnego monopolu „klas wyższych” w społeczeństwie rosyjskim, przedrewolucyjnym, robotnicy nie mogą samodzielnie wykonywać niezbędnych funkcji w państwie - technicznych, organizacyjnych i administracyjnych. Sprawuje je dawna inteligencja (co przewidywał Machajski), a to stwarza zagrożenie, że może się ona przekształcić w „rodzaj nowej klasy [podkreślenie - M.J.Z.], nowej formacji społecznej”. Może wystąpić zjawisko połączenia inteligencji i części komunistycznej elity partyjnej, obejmującej również robotników, ale tylko tych, którzy są oderwani, w związku z pełnionymi funkcjami, od mas pracujących i asymilowani kulturowo przez inteligencję. W rezultacie „niewykluczone jest wyłonienie się nowej klasy [...] podczas gdy klasa robotnicza stanie się klasą wyzyskiwaną [podkreślenie - M.J.Z.]”. Aby temu zapobiec, należałoby jak najszybciej i najszerzej upowszechnić kształcenie robotników, znosząc „przeciwieństwo między tymi, co wiedzą, i tymi, którzy nie wiedzą" ${ }^{19}$. W tym miejscu trzeba zaznaczyć, iż obawę, że porewolucyjna nacjonalizacja gospodarki może przynieść nie tyle wyzwolenie robotników, co powstanie nowej klasy, grupy wyzyskującej proletariat, w tym wypadku za pomocą aparatu władzy, widać w pismach także polskiego filozofa, socjologa i działacza społecznego Edwarda Abramowskiego (1868-1918) ${ }^{20}$.

\footnotetext{
16 L. Kołakowski, Główne nurty marksizmu, t. 3, Warszawa 2009, s. 169.

17 R. Pipes, Rosja bolszewików, tłum. W. Jeżewski, Warszawa 2005, s. 467 i przypis *, s. 467; zob. też: A. Walicki, O Rosji inaczej, Warszawa 2019, s. 178.

18 D. Wolkogonow, Trockij, t. 1, Moskwa 1992, s. 379-380; R. Pipes, op. cit., s. 473.

19 N. Bucharin, Proletarskaja rewolucija i kultura, Piotrogrod 1923, s. 43, 44, 47; P. Laskowski, Jan Wacław Machajski: jasnowidz i prorok, w: J.W. Machajski, Pracownik umysłowy..., s. 53-54.

20 Także Stanisława Brzozowskiego, zob. A. Walicki, O inteligencji, liberalizmach i o Rosji, Kraków 2007, s. 62-66; L. Dubel, Zapomniany prorok rewolucji. Szkic o Janie Wacławie Machajskim, Lublin 2009, s. 121-124.
} 
Bucharin nie był jedynym komunistą sowieckim zaniepokojonym możliwościami powstania „nowej klasy”. Dostrzegał je także np. Chrystian Rakowski, choć nie nazywał tej grupy „nową klasą”. W sierpniu 1928 r. pisał o zróżnicowaniu w ramach poszczególnych klas, np. w burżuazji angielskiej składającej się „z szeregu grup, a nawet klas ekonomicznych”, z „wielkiej, średniej i drobnej burżuazji”, z burżuazji finansowej, handlowej, przemysłowej i rolniczej. Jego zdaniem takież zróżnicowanie w ramach jednej klasy występuje także w socjalistycznym państwie. Charakterystyczne jest to, że „kiedy klasa zdobywa władzę jedna z jej części staje się czynnikiem tej władzy". W socjalistycznym organizmie państwowym na początku występuje zróżnicowanie funkcjonalne, a następnie społeczne. Pojawiają się komuniści, którzy mają „do dyspozycji samochód, ładne mieszkanie, regularne wakacje i otrzymują maksymalną pensję dozwoloną przez partię; pozycję, która się różni od pozycji komunisty pracującego w kopalniach węgla i otrzymującego pensję w wysokości pięćdziesięciu czy sześćdziesięciu rubli”. Ponadto „pewne funkcje które poprzednio były spełnione przez partię jako całość, przez całą klasę, stały się teraz atrybutami władzy, to znaczy tylko pewnej liczby osób w partii i w tej klasie". W rezultacie powstaje „biurokracja rad i partii”, która stanowi „nowy porządek”. Mamy do czynienia $\mathrm{z}$ „nową kategorią społeczną, której należy poświęcić cały traktat”21.

Zdecydowanym przeciwnikiem biurokracji był Trocki, szczególnie po pozbawieniu go władzy w 1924 r. Jego zdaniem zbiegło się to w czasie z sowieckim termidorem, który nie był jednakże równoznaczny z kapitalistyczną kontrrewolucją, lecz z przejęciem władzy właśnie przez biurokrację, która poczęła niszczyć „awangardę proletariacką" ${ }^{22}$. Ten zwolennik permanentnej rewolucji pisał, że sowiecka biurokracja "jest ignorancka i nieokrzesana, niczego [...] się nie uczy, jest nielojalna i zachowuje się po grubiańsku”; że „pochłania [...], marnuje i sprzeniewierza znaczną część dochodu narodowego". Niemniej jej przedstawiciele nie są wyzyskiwaczami, tylko „pasożytami”; nie stanowią „klasy wyzyskiwaczy, lecz pasożytniczą korporację”, klikę, kastę ${ }^{23}$. Są produktem „stalinizmu”, będącego „syfilisem

${ }^{21}$ Ch. Rakowski, „Zawodowe niebezpieczeństwa” władzy, 1917, net.pl/node/23364; tekst anglojęzyczny: https://www.marxists.org/archive/rakowsky/1928/08/prodanger.htm (dostęp: 9.07.2019). Na wspomniany list Rakowskiego powołuje się Marko Babić w pracy Fenomen dysydenta jugosłowiańskiego. Przypadek Milovana Djilasa, Warszawa 2015. Babić cytuje w niej fragment wypowiedzi Rakowskiego, którego nie ma w tekście jego listu, powołując się przy tym na pracę Aleksandra Stojanovicia, Birokratija i tehnokratija, Beograd 1966, s. 251. Oto treść tego fragmentu: „Przed naszymi oczami formuje się wielka klasa panujących, która ma swoje permanentnie rosnące wewnętrzne podziały, która się rozrasta drogą kooptacji i bezpośredniego lub pośredniego intronizowania (awanse biurokratyczne, fikcyjny system wyborczy). U podstaw tej oryginalnej klasy leży równie oryginalna własność prywatna, czyli posiadanie władzy państwowej”, M. Babić, op. cit., s. 68. Być może powyższy cytat pochodzi z innego źródła. Niewątpliwie jest zgodny z logiką wypowiedzi Rakowskiego, ale taka nieścisłość nie powinna występować w pracach naukowych. Nie jest ona jedyna. Piszący te słowa w bibliografii Babicia występuje jako Jerzy Marek Zachariasz (sic!).

22 L. Kołakowski, op. cit., t. 3, s. 197.

${ }^{23}$ L. Trocki, Klasowy charakter państwa radzieckiego, [b.m.d.w], s. 11, 12. 
ruchu robotniczego" 24 . Prześladują i niewolą klasę robotniczą, ale tylko politycznie, ponieważ społeczna własność środków produkcji została zachowana, co świadczy o tym, że utrzymano również dyktaturę proletariatu. To wyraźne contradictio in adiecto skłoniło Leszka Kołakowskiego do ironicznego, lecz trafnego sądu, że w ujęciu Trockiego „klasa robotnicza została całkowicie wywłaszczona politycznie, pozbawiona wszelkich praw, ale ta sama klasa robotnicza sprawuje nadal dyktaturę, ponieważ fabryki i ziemia są własnością państwową"25. Można by tu więc przytoczyć ocenę Milovana Đilasa, że będąc człowiekiem „wielkiej kultury umysłowej i wnikliwej inteligencji”, Trocki wykazywał wszakże ,jeden wielki brak: poczucia rzeczywistości" ${ }^{26}$. Znakomicie pasuje do niego metaforyczne określenie Saula Bellowa, że „można użyć skarbów inteligencji w służbie głupoty, jeśli dość silna jest potrzeba złudzeń" ${ }^{\prime 2}$. Odpowiada ono także twierdzeniu Trockiego, że ten stalinowski, $\mathrm{w}$ istocie termidoriański system wkrótce upadnie, gdyż sprzeciwia się „prawom historii”. Usunie go rewolucja polityczna, nie socjalna, społeczna, ponieważ nie zmieni systemu własności, tylko siłą usunie uzurpatorów. Zmiecie ich „awangarda proletariatu”, wierna tradycjom „prawdziwego bolszewizmu”, niszczonego przez Josifa Wissarionowicza ${ }^{28}$.

Takich złudzeń nie miał wybitny rosyjski filozof Nikołaj Bierdiajew (18741948). Początkowo zwolennik tzw. legalnego marksizmu ${ }^{29}$, w wieku dojrzałym uplasował się na pozycjach konserwatywnych, mistyczno-chrześcijańskich. Głosił, że sowieckie państwo jest tworem „epoki dyktatury”. Chodzi tu nie tylko o dyktaturę polityczną i ekonomiczną, ale również o dyktaturę sprawowaną „nad duchem, nad sumieniem, nad myślą. Dyktatura ta sięga po wszelkie możliwe środki. Jest to ideokracja, pseudomorfoza teokracji, jedna $\mathrm{z}$ transformacji utopii Platona"30. Mając na myśli rozwiązania socjalistyczne, pisał też, iż wszelkie „próby urzeczywistnienia raju na ziemi prowadzą do piekła na ziemi, do uwolnienia sił zła, do nienawiści, wzajemnych rzezi, krwi, gwałtu i orgii [...]. Nigdy w historii nie ziszcza się to, czego oczekują marzyciele"31. Jak zobaczymy, w dużej mierze są to stwierdzenia korespondujące z przemyśleniami Đilasa, początkowo

${ }^{24}$ Idem, Writings of Leon Trotsky (1937-1938), New York 1970, s. 78; M. Babić, op. cit., s. 82.

${ }^{25}$ L. Kołakowski, op. cit., t. 3, s. 219.

${ }^{26}$ M. Dżilas, Nowa klasa..., s. 59.

27 S. Bellow, To Jerusalem and Back, New York 1976, s. 162.

28 L. Kołakowski, op. cit., t. 3, s. 197.

29 „Legalny marksizm” był nurtem myśli społecznej opartej na teorii marksizmu, rozpowszechnianej w kołach inteligenckich Petersburga i Moskwy na przełomie XIX i XX w. Jego przedstawiciele interesowali się głównie ekonomiczną treścią teorii Marksa i Engelsa, odcinali natomiast od politycznej, m.in. walki klas i rewolucji. Uważali kapitalizm za ustrój reformowalny, ulegający postępowym, pokojowym przemianom pożądanym przez ogół społeczeństwa. Szczegóły zob. ibidem, t. 2, Warszawa 2009, s. 374 n.

30 M. Bierdiajew, Źródła i sens komunizmu rosyjskiego, tłum. i oprac. H. Paprocki, Kąty 2005, s. 123.

${ }^{31} \mathrm{Idem}$, O rosyjskiej rewolucji: Oskarżenia rosyjskiej inteligencji, www.konserwatyzm.pl/mikolajbierdiajew-o-rosyjskiej-rewolucji-oskarzenie-rosyjskiej-inteligencji-cz-i/ (dostęp: 15.11.2016). 
bezkrytycznego stalinisty, a następnie wnikliwego analityka i krytyka wszelkich form komunizmu.

Milovan Đilas, urodzony 11 czerwca 1911 r. we wsi Podbišće w Czarnogórze ${ }^{32}$, był człowiekiem wszechstronnie uzdolnionym. W swoim długim życiu - zmarł 20 kwietnia 1995 r. w Belgradzie - imał się różnych zajęć, sprawował różne funkcje. Był politykiem, propagandystą, agitatorem, teoretykiem i analitykiem politycznym, myślicielem, a także literatem, tłumaczem, po $1954 \mathrm{r}$. zaś jeśli nie pierwszym, to jednym z pierwszych dysydentów, zdecydowanym przeciwnikiem i krytykiem komunizmu. Posiadał wyraźne predylekcje do rozważań teoretycznych, wybitny zmysł obserwacji, umiejętności i skłonności do wnikliwej i krytycznej oceny sytuacji oraz - last but not least - duży talent literacki. Bardzo trafne zdaje się stwierdzenie, że z powołania był literatem, z zawodu politykiem, a ponadto utalentowanym mówcą i narratorem ${ }^{33}$. Można by tu dodać, że posiadał także, a ściślej że z czasem uzyskał również pozycję wybitnego intelektualisty ${ }^{34}$. Nowa klasa przyniosła mu ogromny rozgłos w świecie i zapoczątkowała publikację kolejnych prac poświęconych szeroko pojętej problematyce politycznej i ustrojowej. A także kwestiom związanym, ale i wykraczającym poza te zagadnienia, czyli związkom między ideami, utopiami i rzeczywistością ${ }^{35}$. Wspomniane prace staną się podstawą do rekonstrukcji poglądów Đilasa w niniejszym artykule ${ }^{36}$.

W publikacjach poświęconych jugosłowiańskiemu politykowi i myślicielowi często podkreśla się jego przywiązanie do kultury, tradycji i historii jego rodzinnej Czarnogóry. Miało ono wpływać na jego dojrzewanie, kształtowanie osobowości, na wybory życiowe, polityczne, intelektualne. A także rozbudzać jego zainteresowania, nie tylko polityczne, ale i społeczne, idące $\mathrm{w}$ parze $\mathrm{z}$ coraz większą fascynacją sztuką, poezją, literaturą piękną; zainteresowania tak widoczne u tego buntownika, rewolucjonisty i przyszłego odstępcy od komunizmu. Często również uwypukla się jego uwielbienie dla Piotra II Njegoša (1813-1851), władyki (metropolity) i władcy Czarnogóry, a zarazem wybitnego poety, autora poematu

32 S. Clissold, Djilas. The Progress of a Revolutionary, Hounslow-Middlesex 1983, s. 1; A. Đilas, Đido, w: M. Đilas, Pisma iz zatvora, Beograd 2016, s. 332.

${ }^{33}$ Ze wstępu do wywiadu: Milovan Đilas 1989 godine: Kako je nastalo samoupravljanje i kako je nestao komunizam, archiwa.nedeljnik.r.s/velike price/portalnews/milovan-dilas-1989-godine-kako-je-nastalo-samouprawljanje-i-kako-je-nestalo-komunizam (dostęp: 30.07.2019).

${ }^{34}$ Intelektualisty uważanego za jednego z najwybitniejszych analityków komunizmu i publikującego, po politycznym upadku na początku 1954 r., w najpoważniejszych pismach zachodnich. Zob. V. Stanić, „Unutrašnji emigrant”: političke ideje Milovana Đilasa 1954-1989, „Poznańskie Studia Slawistyczne" (2014), nr 6, s. 251.

35 Por. M.J. Zacharias, Idee, utopie, rzeczywistość. Myśl polityczna Milovana Đilasa (1911-1995), Bydgoszcz 2015, passim.

${ }^{36}$ Wykaz najważniejszych wykorzystanych prac Đilasa znajduje się w bibliografii. 
Wieniec górski $i^{37}$. Przykład Njegoša, łączącego „poezję z władzą”, w dużym stopniu był wzorem, o którym Đilas marzył przez całe życie. Wzorem człowieka z powodzeniem łączącego politykę z poezją, z literaturąa ${ }^{38}$. Myśl, by zostać pisarzem, może dziennikarzem, towarzyszyła przecież późniejszym wyborom i zainteresowaniom politycznym Đilasa ${ }^{39}$.

Należy podkreślić, że dzieje i tradycje Czarnogóry, peryferyjnego kraju europejskiego, pełne były okrucieństwa, krwawych porachunków, wojen. Zarówno zewnętrznych, w obronie niezależności, w obliczu zagrożenia zewnętrznego, głównie ze strony Turcji, jak i wewnętrznych, między różnymi rodami i klanami, od stuleci rywalizującymi między sobą, często przy użyciu siły. Đilas będzie później pisał, że kolejne pokolenia zastępowały poprzednie, ale „krwawy łańcuch pozostawał nienaruszony. Odziedziczony strach i nienawiść zwalczających się klanów były silniejsze od strachu i nienawiści do wroga - Turków. Moje pierwsze spojrzenie wiąże się z widokiem krwi. Moje pierwsze słowa mówiły o krwi i skąpaniu we krwi" ${ }^{40}$. Tym krwawym porachunkom towarzyszyły, a być może pogłębiały je, podziały i właśnie religijne, różne rozumienie chrześcijaństwa, konsekwencje dawnych, średniowiecznych oddziaływań herezji tzw. Bogomiłów, powstałej pod wpływami manicheizmu i bizantyjskich paulikian ${ }^{41}$. W rezultacie podkreśla się, że pełna gwałtu, krwawych konfliktów historia Czarnogóry premiowała czy też wytwarzała postawy skrajne, irracjonalne, fanatyczne, radykalne, idealistyczne. I że właśnie ona kształtowała osobowość i postępowanie Đilasa, w dużym stopniu idealistycznego fanatyka, $\mathrm{z}$ równym zapałem, oddaniem i szczerością przyjmującego, a następnie odrzucającego stalinowską wersję systemu komunistycznego ${ }^{42}$.

Czy takie sądy są trafne, zgodne z rzeczywistością? Pozbawione jakichkolwiek konkretnych dowodów mogłyby wzbudzać pewną dozę wątpliwości. Jak bowiem powiązać ogólne, być może błędnie zdiagnozowane, charakterystyczne cechy każdego narodu z określoną osobą, bez żadnych przesłanek ku temu? Na szczęście dysponujemy wypowiedziami samego Đilasa, zdającymi się w dużej mierze uwierzytelniać powyższe sądy i opinie. À propos własnej osoby, po latach będzie on mówił, że każdy Czarnogórzec „posiada mocną pamięć historyczną, tradycję, określone, specyficzne właściwości psychiczne" ${ }^{33}$. W innej wypowiedzi będzie stwierdzał, że Czarnogórcy mają „buntowniczą naturę”, gwałtowny charakter, skłonności „do bohaterszczyzny”, upodobanie do kultu bohaterów. Czarnogórski „charakter

37 Por. M.M. Lustig, Djilas and the Path to Yugoslav Communism, w: idem, Trotsky and Djilas. Critics of Communist Bureaucracy, New York-London 1989, s. 71.

38 M.M. Lustig, Djilas and the Path..., s. 80.

39 S. Clissold, op. cit., s. 11.

40 M. Djilas, Land Without Justice. An Autobiography of His Youth, London 1958, s. 25.

${ }^{41}$ B. Raditsa, The Idealism of Milovan Djilas, „Commentary” (II 1963), s. 149-152, Commentarymagazine.com/articles/the-idealism-of milovan-djilas (dostęp: 15.07.2019).

42 Ibidem.

${ }^{43}$ Milovan Đilas 1989 godine... 
narodowy zdradza wyraźne pokrewieństwo z tym, co potocznie uchodzi za marksizm-leninizm. W marksiście-leniniście czarnogórski buntownik natychmiast rozpozna bratnią duszę. Czarnogórski temperament i duch marksizmu (a zwłaszcza leninizmu) wyraźnie do siebie pasują". W tej samej wypowiedzi Đilas potwierdzi więc, że jego „czarnogórska buntowniczość znalazła naturalne ujście w marksizmie-leninizmie”; że on i inni „czarnogórscy rewolucjoniści” byli „równie dogmatyczni, równie niezdolni do odstąpienia od jednostronnego widzenia faktów i równie zdeterminowani do działania na podstawie tego jednostronnego obrazu rzeczy. Jako młody komunista odrzucałem stary reżim $\mathrm{z}$ taką samą bezkompromisową determinacją, z jaką dziś odrzucam komunizm. Byłem i jestem Czarnogórcem" ${ }^{4}$. Czarnogórcem - a więc buntownikiem $\mathrm{z}$ natury.

Powyższe wypowiedzi autora Nowej klasy należałoby uzupełnić stwierdzeniem, że jego motywacje nie do końca jednakże były jedynie irracjonalne, impulsywne; że jego buntownicza natura, buntowniczy sprzeciw pchający go w stronę komunizmu był równoważony pewną racjonalizacją. Po latach napisze: „stałem się komunistą, bo rzeczywistość nie była po mojej myśli [...] byłem nań skazany z powodu swej natury: niezgody na bezprawie, zrozumienia dla ubogich, sprzeciwu wobec przemocy, wiary w naturalną równość ludzi [...] tęsknoty do absolutnej wolności i wiary w realność drogi, która do niej prowadzi jako do ostatecznego celu"45. Chodziło mu o zasadnicze przemiany, budowę „lepszego, szczęśliwszego życia”, z wykorzystaniem rewolucyjnych idei, metod, działań. We wspomnieniach stwierdzi, że gdy doń przystępował, na początku lat trzydziestych XX stulecia, komunizm był ideą nową, „młodzieńczym entuzjazmem”, „życzeniem”, „wysiłkiem”, „poświęceniem”, gwarancją „lepszego, szczęśliwszego życia”. Paniczne starania „zachowania dawnych form i stosunków”, czynione przez „stróży status quo" w międzywojennej królewskiej Jugosławii, mogły tylko pogłębiać przekonanie „młodego człowieka” o atrakcyjności „wielkiej rewolucji”" ${ }^{46}$. „Większość z nas, młodych ludzi, stała się rewolucjonistami mając nadzieję urzeczywistnienia braterstwa i równości, zniesienia wyzysku ludzi pracy. Zapewnienia im szczęśliwego życia" ${ }^{47}$.

Po latach Đilas określał siebie jako byłego „wyznawcę” komunizmu. Równocześnie podkreślał, że niezależnie od przedstawionych powyżej ideałów i nadziei nie miał złudzeń. Uważał, że rewolucji nie można przeprowadzić bez aktów fanatyzmu, bez względu na jego negatywne konsekwencje. $Z$ punktu widzenia skuteczności rewolucyjnych procesów posiada on bowiem „określone wartości”. Liczą się tylko ogólne zasady i ideały, wszystko inne jest bez znaczenia. „Wierzyłem, że [...] społeczeństwo bezklasowe jest możliwe”, że droga, która doń prowadzi,

${ }^{44}$ M. Dżilas, Chrystas i komisarz, w: Stalin i stalinizm. Rozmowy George’a Urbana, Londyn 1987, s. $193,194$.

45 Idem, Rozvojmog političkog mišljenja, cz. I, http:/milovandjilas/Tekstovi/razvoj\%20mogpolitickog\%misljenja.pdf (dostęp: 15.06.2014).

${ }^{46}$ Idem, Land Without Justice..., s. 302-303.

47 Idem, Memoir of a Revolutionary, New York 1973, s. 92-93. 
jest kręta, że „czekają nas ciężkie walki”, akty bezprawia, niesprawiedliwości, ale „u kresu będzie tak, jak sobie wyobrażaliśmy”48, Można by powiedzieć, że Đilas przewidywał postępowanie zgodne z zasadą, że cel uświęca środki.

Należałoby stwierdzić, że Đilas rozpoczynał swoją buntowniczą, rewolucyjną działalność w szczególnym momencie, na początku lat trzydziestych, gdy partia jugosłowiańskich komunistów zaczynała zmieniać swój charakter. Powstała już w 1919 r., jako Socjalistyczna Partia Robotnicza Jugosławii, rok później zaczęła występować pod nazwą Komunistyczna Partia Jugosławii (KPJ), w 1921 r. została zdelegalizowana. W latach dwudziestych działały w niej różne frakcje, dużą rolę odgrywali lewicowi intelektualiści, wiele miejsca poświęcano problemom teoretycznym, mniej lub więcej związanym z problematyką ruchu robotniczego, toczono dyskusje i polemiki. Jak pisze jeden ze znawców zagadnienia, „«duch partyjny» był bardziej demokratyczny i mniej zdolny do organizowania akcji politycznych" ${ }^{\text {" }}$. W partii dużą rolę odgrywał Sima Marković, przywódca „prawicowej frakcji”, który zdaniem Đilasa "nigdy nie był prawdziwym rewolucjonistą”, "nigdy nie potrafił stać się komunistą w rozumieniu leninowsko-stalinowskim" ${ }^{\circ 0}$. Opinie te potwierdza Miodrag Rašković, pisząc, że jako przywódca "prawicowego skrzydła” w partii Markowić wszedł w konflikt ze Stalinem i Kominternem ${ }^{51}$. W latach trzydziestych następowała stopniowa zmiana tej sytuacji, coraz bardziej ujawniały się walki o władzę, niewątpliwie w związku z polityką Stalina i „czystkami” politycznymi w „Kraju Rad”. Miały one miejsce niezależnie od faktu, że przedstawiciele jednego z nurtów tej walki byli „pod kluczem” w więzieniu w Sremskiej Mitrovicy, drugiego zaś - za granicą ${ }^{52}$. Ponadto wśród intelektualistów związanych z partią członkostwem lub sympatiami - toczyły się spory i dyskusje, których oś stanowiła kwestia, czym powinna być literatura i sztuka: instrumentem walki politycznej, podporządkowanym partyjnej strategii i taktyce, czy przeciwnie - forum swobodnej ekspresji twórczej, w formie i treści ${ }^{53}$.

W latach trzydziestych i bezpośrednio przed agresją państw osi w kwietniu 1941 r. KPJ była słaba, liczyła, podług różnych szacunków, zaledwie 7-12 tys. członków, a zdaniem Stephena Clissolda - jeszcze mniej, ok. 3 tys. ${ }^{54}$ Według Đilasa

48 Milovan Đilas 1989 godine...

${ }^{49}$ M. Babić, op. cit., s. 27-29.

${ }^{50}$ M. Djilas, Memoir of a Revolutionary..., s. 69-70.

${ }^{51}$ M. Rašković, Sima Marković (1888-1939), www.mi.sanu.ac.rs/History/marković.htm (dostęp: 17.06.2014).

52 M. Radovčić, Milovan Đilas u sukobu na književnoj ljevici. Diplomski rad, s. 6, darhiv.ff.unizg. hr/ig/eprint/2410/2/Dilas\%2520diplomski.pdf (dostęp: 22.06.2019).

53 S. Lasić, Sukob na kniževnoj ljevici 1928-1952, Zagreb 1970, passim; M. Radovčić, op. cit., s. 9 n.

54 S. Clissold, op. cit., s. 37; zob. też: J. Marjanović, Narodnooslabodilački rat i socijalistička revolucija, Beograd 1965, s. 81-82; P. Morača, Jugoslawija 1941, Beograd 1971, s. 105; B. Petranović, AVNOJ. Revolucionarna smena vlasti 1942-1945, Beograd 1976, s. 26; idem, Revolucija i kontrarevolucija u Jugoslaviji (1941-1945), t. 1, Beograd 1983, s. 162; D. Bilandžić, Hrvatska moderna povijest, Zagreb 1999, s. 117. 
gdyby nie doszło do wybuchu II wojny światowej, KPJ miałaby jedynie pewną liczbę posłów w parlamencie - w przypadku demokratyzacji kraju i legalizacji partii i bez porównania mniejsze wpływy niż najsilniejsze partie w Jugosławii ${ }^{55}$. Posiadała niewielkie poparcie wśród mas robotniczych, nieprzekraczających 730 tys. osób, jedynie $\mathrm{w}$ połowie zatrudnionych $\mathrm{w}$ przemyśle ${ }^{56} \mathrm{i}$ bynajmniej nie odznaczających się szczególnym „radykalizmem przekonań” ${ }^{57}$. Nieliczne robotnicze, komunistyczne komórki szybko były wykrywane i likwidowane przez władze ${ }^{58}$. Đilas twierdził, że „aż do końca 1942 r.” nie miał kontaktu z robotnikami, ściślej - z komunistami wywodzącymi się z robotników. „Nie było żadnego aktywniejszego i szerokiego ruchu robotniczego”, m.in. dlatego, że „partia była rozbita”, dyktatura zaś króla Aleksandra, wprowadzona w 1929 r., „spustoszyła i zniszczyła (jakiekolwiek) życie polityczne, nie tylko wśród komunistów" 59 . Jak informowała brytyjska ambasada w raporcie dla Foreign Office, jedynie w Belgradzie było ok. 10 tys. studentów. Połowa, a może nawet trzy czwarte z nich miało reprezentować „orientację komunistyczną”, głównie z powodu „strachu przed przyszłością. W Jugosławii istnieje proletariat intelektualny, który domaga się chleba i pracy". W rezultacie jugosłowiański ruch komunistyczny był wyrazem protestu przede wszystkim „inteligencji i intelektualistów"60.

Do powyższej grupy należałoby zaliczyć właśnie Đilasa, który po ukończeniu nauki w czarnogórskich miejscowościach Kolašin i Berane rozpoczął studia na Wydziale Filozoficznym Uniwersytetu w Belgradzie ${ }^{61}$. Starał się godzić pasje i zainteresowania literackie $\mathrm{z}$ działalnością polityczną. $\mathrm{W}$ różnych czasopismach publikował „poezje, opowiadania, przeglądy krytyczno-literackie, eseje oraz artykuły z pogranicza problematyki kulturalnej i politycznej”. Równocześnie angażował się, jak wielu innych studentów, w zwalczanie dyktatury, manifestacje i demonstracje polityczne. W 1932 r. ostatecznie i "bezwarunkowo" aprobował idee i działania komunistyczne ${ }^{62}$. Uczestniczył w przygotowywaniu różnych protestów, organizowaniu struktur komunistycznych na uniwersytecie. W lutym 1932 r. został po raz pierwszy aresztowany, ale po upływie kilkunastu dni wypuszczony z powodu braku dowodów ${ }^{63}$. Ponownie trafił do aresztu wiosną $1933 \mathrm{r}$. Tym razem miał spędzić $\mathrm{w}$ więzieniu pełne trzy lata. Początkowo na wyspie na rzece Sawa ${ }^{64}$, a następnie od końca 1933 r. - w Sremskiej Mitrovicy.

\footnotetext{
55 Milovan Đilas 1989 godine...

56 V. Dedijer, Novi prilozi za biografiju Josipa Broza Tita, t. 2, Rijeka-Zagreb 1982, s. 936.

57 J. Pirjevec, Tito, tłum. J. Pomorska, J. Sławińska, Warszawa 2018, s. 88.

58 M. Djilas, Memoir of a Revolutionary..., s. 96-97.

59 B. Kovačević, Đilas. Heroj-antiheroj-iskazi za istoriju. Drugo prošireno izdanje, Podgorica 2006, S. 80 .

60 J. Pirjevec, op. cit., s. 88.

61 A. Đilas, op. cit., s. 332.

62 Ibidem, s. 332-333; M. Radovčić, op. cit., s. 14.

63 S. Clissold, op. cit., s. 18-19; A. Đilas, op. cit., s. 333.

64 Noszącej dawną nazwę turecką Ada Ciganlija. Zob. S. Clissold, op. cit., s. 22.
} 
W działalności literackiej, przede wszystkim zaś politycznej, Đilas okopywał się na pozycjach skrajnych, możliwie najbardziej buntowniczych i rewolucyjnych. Miało to miejsce także w więzieniu w Sremskiej Mitrovicy. Było to możliwe również dlatego, że władze więzienne wykazywały się pewną tolerancją, co powodowało, że więzieni „członkowie partii mieli możliwości korzystania z bibliotek, organizowali dyskusje, uczyli się", kontaktowali między sobą ${ }^{65}$. To właśnie tam po raz pierwszy Đilas zetknął się z różnymi działaczami partyjnymi, m.in. z Petkiem Mileticiem, Borisem Kidriciem, Andriją Hebrangiem, Aleksandrem Rankoviciem, Mošą Pijadem - serbskim Żydem, tłumaczem Kapitału Marksa. Większość z nich weszła do późniejszego, ścisłego kierownictwa partii. Đilas poznał wówczas prawdziwą, rzeczywistą atmosferę partyjną - wymogi surowej dyscypliny, intrygi i walkę o władzę w KPJ ${ }^{66}$. Zbliżył się do Mileticia i jego zwolenników, wśród których był wówczas także Ranković. Grupa zyskała nazwę „wahabitów”, w nawiązaniu do odłamu religijno-politycznego w islamie, powstałego w XVIII stuleciu na Półwyspie Arabskim; do jego surowości, prostoty, czystości wiary, radykalizmu w działaniu. Miletić pretendował do najwyższych stanowisk w partii, wspomniany zaś „,wahabizm” bardziej był kultem jego osoby niż linią polityczną. "Wahabici” zaś, już po uwolnieniu Đilasa, planowali nawet fizyczne ataki na pozostałości „prawicowej” frakcji, m.in. zabicie Hebranga, co zakończyło się niepowodzeniem ${ }^{67}$.

Niezależnie od powyższego, podobnie jak inni więzieni komuniści, Đilas poświęcał się studiowaniu marksizmu-leninizmu. W miarę upływu czasu ich „absolutnym i niezaprzeczalnym autorytetem marksistowskim” stawał się Stalin. Później Đilas będzie pisał, że „stalinowska odmiana leninizmu” brała wówczas "górę w jugosłowiańskiej partii”, choć równocześnie podkreślał, że nie było to równoznaczne z tym, co zazwyczaj rozumie się pod pojęciem "stalinizmu”. Jego zdaniem autorytet Stalina był bezsporny, „ale tylko jako przywódcy, a nie ucieleśnienia idei i ruchu". Stalinizm miał być w partii przyjmowany głównie jako ruch rewolucyjny, $\mathrm{z}$ Josifem Wissarionowiczem $\mathrm{w}$ roli wodza, ale nie jako system władzy z wyraźnymi tendencjami do tyranii ${ }^{68}$.

Bliska przyszłość miała wykazać, iż rzeczywistość była bardziej skomplikowana, że niekoniecznie pokrywała się ze stwierdzeniami „wahabity” Đilasa. Tak czy inaczej trafna wydaje się ocena, iż jego marksizm miał rosyjskie korzenie, że był zgodny z poglądami Lenina i Stalina, a nie z treścią oryginalnych prac Marksa i jego zachodnich interpretatorów. "Jedynie rosyjskie rozumienie rewolucyjnego procesu było jego zdaniem odpowiednie dla takiego kraju jak Czarnogóra [od siebie moglibyśmy dodać - jak Jugosławia, M.J.Z]”; kraju, dla którego podstawową

${ }^{65}$ M. Babić, op. cit., s. 29-30.

${ }^{66}$ M. Đilas, Memoir of a Revolutionary..., s. 142 n., 152, 190; S. Clissold, op. cit., s. 23.

67 J. Banac, With Stalin Against Tito. Communist Splits in Yugoslaw Communism, Ithaca-London 1988, s. 65-67; N. Kisić Kolanović, Hebrang. Iluzjie i otrežnjenja, Zagreb 1996, s. 32, 34-35; M. Babić, op. cit., s. 31.

${ }^{68}$ M.J. Zacharias, Idee, utopie, rzeczywistość..., s. 35-36. 
sprawą, „jak często powtarzał, było to, w jaki sposób wprowadzić sprawiedliwość, skoro jego społeczeństwo nigdy jej nie zaznało". Głosił, że wprowadzenie jakiejkolwiek formy sprawiedliwości, odpowiadającej wschodnio- czy południowo-wschodnim ludom słowiańskim powinno być pochodną „uniwersalnej, duchowej prawdy dotyczącej ludzkiej natury. Podobnie jak Dostojewski”, Đilas nie poczuwał się do związku „z zachodnią interpretacją sprawiedliwości”, uważając ją za przejaw „zdehumanizowanego formalizmu”. Uważał, iż przeciwnie, właśnie „w dalekiej Rosji bolszewików” rodzaj ludzki spotyka „prawdziwą, ludzką sprawiedliwość"69.

Taka postawa Đilasa uwidaczniała się w więzieniu, jak i po jego opuszczeniu w 1936 r. Co więcej, mając na uwadze jego postępowanie po uwolnieniu, nie można się oprzeć wrażeniu, że był on wówczas plus catholique que le pape w Moskwie ${ }^{70}$. W swoich międzywojennych wspomnieniach pisał, że wiosną 1937 r. udał się na spotkanie z pewnym „towarzyszem z Komitetu Centralnego [KC]”, przybyłym z Paryża. „Towarzyszem” okazał się Josip Broz, zwany później Titą ${ }^{71}$. Spotkanie nastąpiło w czasie, gdy Đilas uzyskiwał i umacniał swoją pozycję w partyjnych władzach i właśnie obok Tity, a także Edvarda Kardelja i Rankovicia z wolna stawał się jedną $\mathrm{z}$ pierwszoplanowych postaci $\mathrm{w}$ łonie KPJ. Miało to miejsce w okresie największych stalinowskich „czystek”, których ofiarą padł m.in. Milan Gorkić, dotychczasowy przywódca partii. Jego miejsce stopniowo obejmował właśnie wspomniany Broz. Aresztowaniu Gorkicia towarzyszyły różne knowania, intrygi i spiski, z dosyć niejasną i w istocie dwuznaczną rolą Waltera, jak zwano Broza w Kominternie i w gronie kremlowskiego „gospodarza” Josifa Wissarionowicza ${ }^{72}$. W ich wyniku stracił życie także niegdysiejszy pretendent do władzy, Miletić. Uwolniony z więzienia w królewskiej Jugosławii w czerwcu 1939 r., po przyjeździe do Moskwy „szybko został pojmany przez organa NKWD i przepadł bez śladu w labiryntach sowieckich łagrów"73. Nastąpiło to w końcowej fazie tzw. bolszewizacji KPJ, a więc oczyszczania tej partii $\mathrm{z}$,prawicowych” niedobitków dominujących w latach dwudziestych XX stulecia.

Należałoby stwierdzić, że jedną z pierwszoplanowych postaci tej „bolszewizacji” był właśnie Đilas. „Zbolszewizowana” partia miała propagować i kierować się „myślami Lenina w stalinowskiej interpretacji”, a także ścisłym centralizmem i „militarną dyscypliną”. Mocą decyzji sekretarza politycznego Kominternu Georgiego Dymitrowa z 5 stycznia 1939 r. Tito został upoważniony do utworzenia

69 B. Raditsa, op. cit.

70 Co uwidoczniło się wówczas w zwalczaniu przez Đilasa „dawnych komunistów”, a więc przedstawicieli starej generacji rewolucjonistów, ukształtowanej przed wprowadzeniem dyktatury z $1929 \mathrm{r}$. Jego zdaniem stanowili oni „przeszkodę w tworzeniu nowych organizacji partyjnych” mających prowadzić "masy” do rewolucji. W rezultacie on i jego zwolennicy byli określani przez „starych komunistów" mianem „ «sekciarzy» nie rozumiejących linii Kominternu w sprawie frontu ludowego", powstałej przecież zgodnie z wolą samego Stalina. M. Djilas, Memoir of a Revolutionary..., s. 264.

${ }^{71}$ Ibidem, s. 258-259.

72 Zob. M.J. Zacharias, Idee, utopie, rzeczywistość..., s. 41, przypis 109.

73 I. Banac, op. cit., s. 70. 
nowego KC KPJ ${ }^{74}$. Stanowiło to oficjalne potwierdzenie jego pozycji i przywództwa w partii. „Czystki” i polityka nowego kierownictwa były zgodne z przekonaniem Đilasa, że to „my sami stanowiliśmy najbardziej zwartą grupę bolszewicką"75. Gwarantowana przez nią jedność i dyscyplina miały stanowić zasadniczą przesłankę umacniania wpływów w „masach”; wpływów idących w parze ze wzrostem spodziewanego społecznego niezadowolenia. Miało ono potwierdzać „leninowską" teorię o rosnącej sile partii w miarę pozbywania się „elementów oportunistycznych"76. To właśnie w zgodzie z logiką tej „teorii” wszystkie aspekty postępowania każdego komunisty miały być podporządkowane partii i sprawie przyszłej rewolucji.

Można zaryzykować tezę, że pojęcie „bolszewizacja”, używane przez Đilasa, a także przez innych przywódców partyjnych, z Titą na czele ${ }^{77}$, niezupełnie oddaje istotę rzeczy. Przecież w czasie stalinowskich „czystek” nastąpiła fizyczna eliminacja dawnej, bolszewickiej elity. Towarzyszyła jej wcześniejsza, praktyczna rezygnacja $\mathrm{z}$ ich zasadniczego celu, tj. przeprowadzenia rewolucji światowej niezależnie od takich czy innych celów Rosji. W odróżnieniu od starej, likwidowanej gwardii bolszewickiej z Trockim na czele, Stalin nie traktował „Kraju Rad” tylko i przede wszystkim jako „zapalnika” rewolucji na świecie, a więc instrumentalnie. $\mathrm{W}$ istocie podporządkowywał wszystkie swoje działania państwowym, imperialnym celom Moskwy. Zgodnie z trafną metaforą François Fureta, dorzucając „,do swojego komunizmu dawkę starego nacjonalizmu rosyjskiego”, jesienią 1939 r. zaś uzmysławiając opinii międzynarodowej, że „pojmuje ekspansję w Europie jako zbrojny eksport ustroju sowieckiego pod kontrolą" swoich „agentów"78. Można by tylko dodać, że głównie z pomocą Armii Czerwonej. Chodziło o przeprowadzenie komunizacji $\mathrm{w}$ istocie bez rewolucji, z użyciem przede wszystkim własnej siły militarnej ${ }^{79}$. Ta „oryginalna" strategia Stalina, zmierzającego do osiągnięcia celów rewolucji bez rewolucji, była później trafnie analizowana przez Đilasa ${ }^{80}$. Niezależnie od faktu,

74 J. Broz-Tito, O partiji i ulozi komunista, t. 4: Osvrt na istorijski razwitak KPJ (SKJ) 1919-1940, Beograd 1984, s. 326-327, przypisy 66, 71, 73, s. 358, przypis 259.

75 M. Djilas, Memoir of a Revolutionary..., s. 304.

76 Ibidem, s. 305-344.

77 Przeprowadzając „czystki” w partii, Tito uzasadniał je w artykule pod znamiennym tytułem: $Z a$ čistotu i bolševizaciju partije. I. Banac, op. cit., s. 70-71 i przypis 53.

${ }^{78}$ F. Furet, Przeszłość pewnego złudzenia. Esej o idei komunistycznej w XX w., tłum. J. Górnicka-Kalinowska, M. Ochab, Warszawa 1996, s. 181, 397. Wcześniej podobną, trafną metaforę przedstawił Czesław Miłosz. W Rosji „rewolucja stała się imprezą planowaną przez urzędników Centrum, a rozpowszechnianą przez podbój militarny" (oczywiście na obszarach poza ZSRS), idem, Zniewolony umysł, Kraków 1990, s. 77.

79 Zob. M.J. Zacharias, Światowa rewolucja czy dyplomatyczna kalkulacja? Stalin i początki II wojny światowej, w: Politycy, dyplomaci i żotnierze. Studia $z$ dziejów stosunków międzynarodowych w XX i XXI wieku, ofiarowane Profesorowi Andrzejowi Maciejowi Brzezińskiemu w 70. rocznice urodzin, red. D. Jeziorny, S.M. Nowinowski, R.P. Żurawski vel Grajewski, Łódź 2017, s. 349-366, zwłaszcza 362-364.

80 „Ta wojna - twierdził Stalin - nie jest taka jak w przeszłości. Kto okupuje terytorium, narzuca także własny ustrój społeczny [...] Nie może być inaczej”, M. Dżilas, Rozmowy ze Stalinem, Paryż 1962, s. 87. 
że w czasie II wojny światowej jugosłowiańscy przywódcy komunistyczni łącznie z Đilasem nie rozumieli niuansów polityki Josifa Wissarionowicza. Wyraźna idealizacja jego działań stała się główną przyczyną tarć i napięć między nimi i „wodzem światowego proletariatu". W odniesieniu zaś do sytuacji z przedednia wojny należałoby stwierdzić, że przeprowadzali oni nie tyle bolszewizację, co stalinizację swej partii. Trudno byłoby poważnie traktować bolszewizację i stalinizację jako synonimy ${ }^{81}$.

Ta stalinizacja miała miejsce również na „froncie ideologicznym”, by użyć języka partyjnego. Chodziło o maksymalną instrumentalizację sztuki i literatury, uczynienie z nich poręcznego narzędzia politycznego, zgodnie z założeniami tzw. realizmu socjalistycznego. Temu miała służyć rozprawa z Miroslavem Krležą (18931981), najwybitniejszym, obok Ivo Andricia, laureatem Nagrody Nobla, jugosłowiańskim pisarzem. Krleža od początku, tj. od 1919 r. należał do partii i swoją twórczością, autorytetem niewątpliwie był przydatny. Jeden z czołowych polityków jugosłowiańskich po II wojnie światowej, Vladimir Bakarić stwierdził, że w latach dwudziestych Krleža oddał większe usługi „,ruchowi postępowemu” niż cała partia ${ }^{82}$. Krleža krytycznie odnosił się do zachodnich socjalistów czy socjaldemokratów, nie bardzo wierzył w ich możliwości zastąpienia systemu kapitalistycznego socjalizmem, mówił o niebezpieczeństwie ze strony rosnących, prawicowych ruchów autorytarnych, ale równocześnie był zdegustowany polityką Stalina, wyrażał się o nim krytycznie, a nawet lekceważąco, co Đilasa doprowadzało do wściekłości ${ }^{83}$; dawał też do zrozumienia, że jest przeciwnikiem moskiewskich „czystek” i procesów politycznych. A nade wszystko, że traktuje literaturę jako dziedzinę autonomiczną; dziedzinę swobodnej twórczości, wolnej od politycznych nacisków ${ }^{84}$. Wkrótce też miało się okazać, że niezbyt ceni twórczość literacką tych osobistości, które popierają stalinizację partii. W lutym 1939 r. wraz ze swoimi zwolennikami zaczął wydawać pismo „Pečat” („Pieczęć”). W końcu tego roku opublikował w nim esej pt. Dijalektički antibarbarus, który stał się punktem zwrotnym w sporze na literackiej lewicy ${ }^{85}$.

W chorwackiej tradycji kulturowej, do której należał Krleža, jako Chorwat z pochodzenia, antibarbarus to nazwa swoistego podręcznika językowego, w którym są pospisywane, opisane oraz poddane krytyce i wymianie różne wyrażenia, barbaryzmy, niezgodne z normami języka literackiego ${ }^{86}$. Krleža w swym dziele

${ }^{81}$ Myślę, że w tym wypadku dużo racji ma Lew Trocki, pisząc, że stalinizm w istocie był kontrrewolucyjną negacją bolszewizmu, oddzieloną od leninizmu „przez całą rzekę krwi”. L. Trocki, Stalinism and Bolshevism, New York 1970, s. 17; A. Walicki, O Rosji inaczej..., s. 179, przypis 14.

${ }^{82}$ V. Kalezić, Partijska linija u sećanju Vladimira Bakarića, „Književna reč” (25 XII 1983), s. 8.

${ }^{83}$ Idem, Ljevica u sukobu s Krležom, Beograd 1990, s. 242, 310; M. Radovčić, op. cit., s. 27; Modern Political Thought in East Central Europe, vol. 2: Negotiating Modernity in the „Short Twentieth Century" and Beyond, Part I: 1918-1968, ed. B. Trencsenji, M. Kopček, L. Lišjak Gabrijelčić, M. Falina, M. Baar, M. Janowski, Oxford 2018, s. 136-137.

${ }^{84}$ I. Banac, op. cit., s. 72.

${ }^{85}$ M. Krleža, Dijalektički antibarbarus, „Pečat” (1939), nr 8-9.

${ }^{86}$ Leksikografski zavod Miroslav Krleža, krlezijana.lzmk.hr/clanak.aspx?id=280 (dostęp: 20 VI 2019). 
skrytykował, a nawet wyśmiał swoich oponentów na literackiej lewicy, m.in. właśnie Đilasa. Trafnej, złożonej i twórczej myśli przeciwstawiał mętne, uległe, służalcze myślenie dogmatyczne - „antydialektyczne barbarzyństwo” swoich przeciwników. Zapowiedział obronę powagi, godności „społecznej tendencji” („socijalne tendencije") w literaturze przed literatami pozbawionymi talentu, przed dyletantami; obronę aż do czasu uporządkowania zamętu w pojęciach i formach literackich ${ }^{87}$. Wytknął swym antagonistom posługiwanie się obelgami oraz insynuacjami, a także oskarżenia niewygodnych autorów o sprzyjanie trockistom i szerzenie „politycznego bandytyzmu"88. Choć o Stalinie i jego polityce Krleža nie wspomniał, to swe dzieło napisał tak, że mogło być odczytane jako analiza stalinowskiej mentalności. I jako takie wywołało ono głębokie poruszenie i krytykę ${ }^{89}$.

Wynikiem tego wzburzenia stało się totalne potępienie postawy i twórczości Krležy. Przygotowano specjalny zbiór prac, pt. Književne sveske (Zeszyty literackie), wydany latem 1940 r., w dużej mierze z inicjatywy samego Đilasa ${ }^{90}$. Był on także jednym z autorów 12 artykułów zamieszczonych w tym zbiorze. Krležę posądzano o wszelkie możliwe "grzechy” - zarzucono jemu i jego zwolennikom niedostateczną znajomość marksizmu, rewizjonizm i reakcyjną postawę, a także zapoczątkowanie dyskusji o swobodzie twórczości w czasie, gdy wszelkie siły należałoby skupić na tworzeniu zwartego, jednolitego frontu walki z przeciwnikami partii i komunizmu. Najostrzejszą krytykę przedstawił Đilas. Jego zdaniem chorwacki pisarz stał się narzędziem „otwartych i ukrytych nieprzyjaciół postępowej myśli”, także trockistów, którzy traktują Dijalektički antibarbarus jako utwór trockistowski. Posługując się cytatami z esejów Krležy, Đilas stwierdzał, że swoje niezrozumienie marksizmu przekształca on $\mathrm{w}$ walkę $\mathrm{z}$ tą teorią. Niezgodnie $\mathrm{z}$ jej treścią przedstawia rolę jednostki w historii, nie rozumie pojęcia "dyktatura proletariatu”, politycznych i ekonomicznych zasad nauki Marksa, leninowskiej analizy imperializmu, roli proletariatu, a nadto wykazuje sympatie dla Grigorija Zinowiewa i Bucharina, którzy okazali się „zdrajcami”. Maskuje swoją rewizjonistyczną postawę, rozbrat z linią partii i „zaangażowanych milionów (sic!)” przykrywa dyskusjami o „literackich talentach i beztalenciach”, o „literackich geniuszach i takowych głupkach”91, rzeczywiste różnice zaś - „kwiecistymi frazami” bez rzeczywistej treści ${ }^{92}$.

${ }^{87}$ M. Krleža, op. cit., s. 134; Đ. Tomić, K. Stojaković, Iz povijesti jugoslovanske ljevice od početka 19. stoljeća do izbijanja drugog svetskog rata. Skića poglava koje ne dostaje, „Perspektive” (2013), nr 7, s. 13-14.

${ }^{88}$ M. Krleža, op. cit., s. 176; I. Banac, op. cit., s. 73.

89 I. Banac, op. cit., s. 73.

90 „Književn sveske” (1940), nr 1; M. Radovčić, op. cit., s. 31.

91 M. Radovčić, op. cit., s. 31-34. Po latach Đilas będzie twierdził, że „z literackiego punktu widzenia” Krleža miał rację, mówiąc, że literatura powinna być niezależna od polityki, że jest ona autonomiczną działalnością. Nie miał jednakże prawa nazywać swych oponentów „głupkami”, ludźmi pozbawionymi talentu. Tym bardziej że jego zwolennicy nie byli bardziej utalentowani. Milovan Đilas 1989 godine...

92 „Književne sveske”, s. 191; M. Radovčić, op. cit., s. 33. 
Ostatecznie komunistyczne władze wstrzymały druk pisma Krležy, a w czasie V Krajowej Konferencji KPJ, odbytej w Zagrzebiu między 19 a 23 listopada 1940 r., Tito potępił Krležę i jego zwolenników za próbę „rewizji marksizmu-leninizmu”93. Zdaniem Đilasa zgadzało się to z logiką ówczesnej sytuacji. Krleža był bowiem "komunistą minionego czasu, sprzed dyktatury”, wprowadzonej w 1929 r., typowym jugosłowiańskim komunistą trzeciego dziesięciolecia XX w. Mocno przywiązanym do roli, jaką miał spełniać w społeczeństwie „wolny i niezależny intelektualista". Ale u schyłku lat trzydziestych partia potrzebowała nie intelektualistów, lecz „wyznawców”, bezkrytycznie przyjmujących dogmaty „wiary”. Jedynie ona mogła wzmacniać i uzasadniać działania komunistów w tym czasie ${ }^{94}$. W istocie stalinistów, których Đilas był wyrazicielem. Stalinowskiej fali w sowieckim, jugosłowiańskim i ogólniej - międzynarodowym ruchu komunistycznym zawdzięczał on swoje wyniesienie i pozycję w KPJ. Identycznie jak pozostali jugosłowiańscy przywódcy komunistyczni aprobował i uzasadniał wewnętrzną i zagraniczną politykę Josifa Wissarionowicza, łącznie z jego postawą wobec mocarstw zachodnich, paktem Ribbentrop-Mołotow z 23 sierpnia 1939 r. i jego konsekwencjami w postaci podziału Polski i państw bałtyckich na strefy wpływów: niemiecką i sowieckąa ${ }^{95}$.

Atak państw osi z III Rzeszą na czele na Jugosławię na początku kwietnia 1940 r. całkowicie zmienił sytuację w tym kraju. Jego rozbiciu i rozczłonkowaniu przez agresorów towarzyszyły okupacja, kolaboracja, ruch oporu, wojna domowa, rewolucja oraz walka o władzę sprawowaną po zakończeniu działań wojennych. W istocie oprócz Albanii i Jugosławii trudno byłoby znaleźć inne państwo europejskie, w którym wszystkie te zjawiska występowałyby równocześnie. Są one dobrze udokumentowane, mają obszerną literaturę naukową ${ }^{96}$. W niniejszym artykule zostaną poruszone jedynie o tyle, o ile wiążą się z biografią Đilasa.

Po ataku Niemiec na Związek Sowiecki 22 czerwca 1941 r., jugosłowiańscy przywódcy komunistyczni na początku lipca tego roku zdecydowali się wezwać swych rodaków do walki zbrojnej. Wojna partyzancka miała być podstawową formą zwalczania okupantów ${ }^{97}$. Đilas pisał, że podjęto ją bez żadnych dyskusji, na podstawie znajomości dyrektywy Kominternu i „naszych ideologicznych, internacjonalistycznych zobowiązań i miłości do ZSRS - «fortecy światowego komunizmu» $i$ "przewodniego kraju socjalistycznego»". Te uczucia i zobowiązania w pełni "harmonizowały z naszą własną sytuacją i aspiracjami”" ${ }^{\text {. W }}$ swoich pamiętnikach autor Nowej klasy wspominał, że tę walkę partyzancką chciał nazwać

93 V. Kalezić, Ljevica u sukobu s Krležom..., s. 345, 346.

94 M. Đilas, Razvoj mog politykog mišlenja..., cz. 5.

95 M.J. Zacharias, Idee, utopie, rzeczywistość..., s. 46 n.

96 W literaturze polskiej: idem, Komunizm, federacja nacjonalizmy. System władzy w Jugosławii 1943-1991. Powstanie, przekształcenia, rozkład, Warszawa 2004, s. 40 n. Spośród prac historyków z dawnego obszaru Jugosławii zob. J. Pirjevec, op. cit., s. $110 \mathrm{n}$.

97 B. Petranović, AVNOJ..., s. 24; J. Pirjevec, op. cit., s. 123 n.

98 M. Djilas, Wartime, New York-London 1977, s. 5. 
„antyfaszystowską rewolucją”. Niemniej Tito i jego najbliżsi współpracownicy mieli być temu przeciwni, oceniając, że samo określenie „rewolucja” nie przystaje do taktyki politycznej Moskwy, głównie wobec Wielkiej Brytanii, i zawęża możliwości wsparcia wewnętrznego, odpychając od komunistów potencjalnych zwolenników w kraju. Ostatecznie zapadła decyzja, by działania ruchu tworzonego przez komunistów określać mianem „walki narodowowyzwoleńczej”. Đilas ją przyjmował, jak pisał, bez entuzjazmu, ale i bez widocznego niezadowolenia. Uważał, że należy być „zdyscyplinowanym, życzliwie przyjmować stanowisko większości”, choć równocześnie zachowywać niezależność myślenia, „nie ulegać pragmatycznym, bieżącym «uogólnieniom»”. Trzeba myśleć „własną głową", robić zaś to, co można i należy, o ile warunki na to pozwalają - zgodnie z własnymi przekonaniami ${ }^{99}$. W pewnej mierze tak było istotnie, choć warto podkreślić, że nie wszystkie działania Đilasa w pierwszych miesiącach po rozpoczęciu komunistycznego powstania są całkowicie jasne.

Wspomniane niejasności wiążą się przede wszystkim z rolą Đilasa w pierwszych miesiącach po proklamowaniu walki z okupantami. Został on wysłany do Czarnogóry, miał tam tworzyć podwaliny ruchu oporu, choć nie $\mathrm{w}$ formie powszechnego powstania ludowego. Twierdząc, że Włosi „są jeszcze silni i dobrze zorganizowani”, Tito polecał mu rozpoczęcie walki „od mniejszych operacji” ${ }^{100}$. Đilas nie bardzo trzymał się tych instrukcji, a ponadto mówił o potrzebie „bliskiej rewolucji antyfaszystowskiej, która nie jest niczym innym jak koniecznym etapem rewolucji proletariackiej" 101 . Taka „rewolucja” byłaby zupełnie niekompatybilna z poglądami i zamysłami przypisywanymi Đilasowi przez jednego z badaczy, Miloša Milikicia Midę. Jego zdaniem Đilas, który jak sam wszakże pisał, miał być przede wszystkim rewolucjonistą, już wtedy, a więc na początku powstania i rewolucji, miał jako pierwszy „sugerować potrzebę utworzenia” „wielopartyjnego i demokratycznego systemu", gwarantującego swobodę myśli, wypowiedzi i zgromadzeń. Milikić Mido cytuje odezwę tymczasowego dowództwa partyzanckiego Czarnogóry, Boki Kotorskiej i Sandżaku z 22 lipca 1941 r., w której faktycznie znajdują się zdania potwierdzające jego opinię. Ale równocześnie zauważa, że Đilas napisał odezwę „w historycznym momencie, w konkretnej sytuacji”, tak aby pozyskać jak największe wsparcie ludu „W walce $\mathrm{z}$ okupantami” ${ }^{102}$. Treść dokumentu byłaby więc dyktowana jedynie względami taktycznymi, nie potwierdzają jej zresztą inne źródła wykorzystane przez Milikicia Midę. O rzekomych zamysłach i poglądach przypisywanych przez niego Đilasowi nie znajdujemy żadnych wzmianek w jego wspomnieniach $\mathrm{z}$ czasów wojny ani $\mathrm{w}$ zarysie biografii Đilasa, sporządzonym przez jego syna Aleksę ${ }^{103}$. Niczego się o nich nie dowiadujemy także z tych prac,

99 Idem, Razwojmog političkog mišljenja..., cz. 6.

100 S. Clissold, op. cit., s. 53; J. Pirjevec, op. cit., s. 128.

101 J. Pirjevec, op. cit., s. 128.

102 M. Milikić Mido, Ratnim stazama Milovana Đilasa, Beograd 2011, s. 52-57.

103 A. Đilas, op. cit., s. 334. 
których autorzy starają się przedstawić działalność Đilasa w Czarnogórze w jak najlepszym świetle ${ }^{104}$.

Nie wszyscy historycy jednakże prezentują taką postawę. Zdaniem słoweńskiego badacza Jože Pirjevca odurzony początkowymi sukcesami Đilas zaczął napadać nie tylko na okupantów, ale i na „wrogów klasowych”, co doprowadziło do znacznego osłabienia komunistów w Czarnogórze. A także do tego, że zrażeni „czerwonym terrorem”, jak to później określano, tzw. lewicowym odchyleniem, Czarnogórcy zaczęli masowo dołączać do konkurencyjnego ruchu oporu, a więc do czetników Dragoljuba (Dražy) Mihailovicia. Według Pirjevca w walce ze „zdradzieckimi kułakami” czarnogórskimi podkomendni Đilasa zdecydowali się przeprowadzić masowe egzekucje oraz opublikować specjalny biuletyn zawierający nazwiska pomordowanych i zapewnienie, że "ciąg dalszy nastąpi” ${ }^{105}$. Trudno byłoby pogodzić te fakty z rzekomym poszanowaniem zasad demokracji.

Podobną oceną można by sformułować w związku z powitaniem misji brytyjskiego Kierownictwa Operacji Specjalnych (Special Operations Executive - SOE), wysłanej do Jugosławii pod wodzą kapitana Duane’a Tyrrella „Billa” Hudsona, 20 września 1941 r. powitanej przez ludzi Đilasa. Została ona przyjęta uprzejmie, ale chłodno, $\mathrm{z}$ widocznym brakiem zaufania. Jugosłowiańscy komuniści zdawali sobie sprawę, że Brytyjczycy są sojusznikami Sowietów, a więc również ich samych. Niemniej mieli zakodowaną głęboką nieufność do „brytyjskiego imperializmu”, do działań Intelligence Service w szczególności. Đilas wspominał, że „komunistyczna prasa” często atakowała tę służbę, że „komuniści szkoleni w Moskwie” zwracali uwagę na wyrafinowane metody działania funkcjonariuszy brytyjskiego wywiadu, że często o nich mówiono w „tzw. procesach moskiewskich”; „,wierzyliśmy [...] że wielu przywódców rosyjskiej rewolucji zostało wprowadzonych w błąd przez zręcznych, sprytnych Anglików”. W jugosłowiańskiej partii „krążyła legenda”, że Gorkić, poprzednik Tity na stanowisku sekretarza generalnego KPJ, „był brytyjskim agentem. Słyszałem o tym - pisał Đilas - od samego Tity, choć nie sądzę, by ten sam ją wymyślił; prawdopodobnie był ofiarą oszustw NKWD”106. Prasa brytyjska zaś rozpowszechniała mity o wszechmocy Intelligence Service. Wszystko to „skłaniało nas do największej ostrożności. W osobie Lawrence’a z Arabii dostrzegaliśmy nie idealnego bohatera, lecz perfidnego, aroganckiego orędownika imperium (brytyjskiego)" 107 . W rezultacie, także pod wpływem wiary, że szybkie zwycięstwa Armii Czerwonej spowodują klęskę Niemiec i stworzą możliwości zwycięstwa rewolucji w Jugosławii, Đilas z rezerwą przyjmował sugestie, że Brytyjczycy mogą zapewnić partyzantom większe dostawy sprzętu wojennego niż Sowieci. Nie przejawiał

104 Zob. M. Cemović, Đilasovi odgovori, Beograd 1997, s. 58-75; V. Pavlićević, Disident Đilas (Polemike, podsjećanja, tumačenja), Podgorica 2016, s. 90-91.

105 J. Pirjevec, op. cit., s. 128-129.

106 M. Djilas, Wartime..., s. 68-69.

107 Ibidem, s. 69. O głębokiej nieufności do Wielkiej Brytanii oraz Intelligence Service w szczególności zob. też: M. Dżilas, Rozmowy ze Stalinem..., s. 19-22. 
entuzjazmu do ustanowienia jakiejkolwiek łączności z Wielką Brytanią. W swej relacji Hudson przytoczył $\mathrm{w}$ związku z tym znamienne słowa Đilasa, który swoim współpracownikom oświadczał: „pamiętajcie, że słońce nie wschodzi na Zachodzie"108.

Powyższa postawa niedwuznacznie świadczyła, że Đilas myślał głównie o rewolucji i wszelkie wzmianki w sprawie demokratycznych swobód mógł traktować jedynie jako taktyczne posunięcia. Co zresztą wzbudzało wątpliwości samego Tity uważającego, iż jego podwładny wykazuje się nadmierną samodzielnością i zbyt wielkim radykalizmem. 5 listopada $1941 \mathrm{r}$. Đilas otrzymał „list od Tity, z jego pieczęcią i podpisem”. Przywódca jugosłowiańskiej partii zwracał uwagę na „błędy” swego podwładnego i odwoływał go z Czarnogóry. Uchybienia miały polegać głównie na przedwczesnym wywołaniu powstania, przed utworzeniem silnych oddziałów partyzanckich, i na nieprawidłowym określaniu walki narodowowyzwoleńczej mianem „antyfaszystowskiej rewolucji”, co różniło się od ówczesnej taktyki partyjnego przywództwa ${ }^{109}$. Zdaniem Pirjevca niezadowolenie przywództwa było tak wielkie, że „niewiele brakowało”, by Đilas „został skazany na karę śmierci, jak to się stało w przypadku wielu innych osób”. Ostatecznie jednakże jej uniknął i co więcej - został „mianowany redaktorem naczelnym «Borby» [«Walka»], głównego organu KPJ, ponownie powołanego do życia po kilkunastoletniej przerwie"110.

Po swym czarnogórskim epizodzie Đilas stopniowo stawał się czołowym propagandystą i ideologiem partyjnym. W czasie wojny było to równoznaczne przede wszystkim z przedstawianiem w samych superlatywach Związku Sowieckiego i jego przywódcy, Josifa Wissarionowicza. Dobrym przykładem w tym względzie może być treść artykułu Đilasa, zamieszczonego w „Borbie” 7 listopada 1942 r. Stalin występuje w nim jako niezwyciężony wódz, najlepszy nauczyciel, najukochańszy ojciec, najwierniejszy przyjaciel, jako „Lenin naszych czasów”, jako „Lenin, który żyje między nami”; jako „towarzysz, który siedzi z tobą na czatach, łagodzi twoje rany, dodaje ci odwagi, byś się nigdy nie załamał; z wdzięcznością spogląda na twoje męstwo i twoje szlachetne pragnienia”. Jest „najzacieklejszym wrogiem wszystkiego co nieludzkie”, przywódcą kraju, „który nie kieruje się ukrytymi motywami $[. .$.$] nic co ludzkie nie jest mu obce [...]. Jest wielkim zaszczytem żyć w cza-$ sach Stalina, walczyć pod jego przewodem i w ten sposób być częścią czegoś, co nigdy nie zginie [...]. Nasza miłość do Związku Sowieckiego jest miłością dozgonną, bo stała się naszym życiem wśród ognia i powodzi, naszą duszą, naszą przyszłością, naszym chlebem powszednim. Jest to miłość wieczysta, bo uszlachetniona duchem

108 British Policy towards Wartime Resistance in Yugoslavia and Greece, ed. Ph. Auty, R. Clogg, London 1975, s. 91-92; M.J. Zacharias, Jugosławia w polityce Wielkiej Brytanii 1940-1945, Wroclaw 1985, s. 60.

109 Zbornik dokumenata i podataka o narodnooslobodilackom ratu jugoslovenskih naroda, t. 3, knj. 1, Beograd 1950, s. 68; M. Djilas, Wartime..., s. 79.

110 J. Pirjevec, op. cit., s. 129; V. Pavlićević, „Lijeve greške” Milovana Đilasa ili partyjski silogizam, Podgorica 2012, s. 23, 26. 
wielkiego Stalina”. Człowieka, który „jest opoką”, najważniejszą, bo „decydującą w dziejach ludzkości"111.

Po latach Đilas twierdził, że idealizacja Stalina w powyższym artykule, podobnie jak w innych, była symptomem pewnego pragmatyzmu. Mówił, że „gdybyśmy nie przyjęli [...] takiej postawy wobec Związku Sowieckiego i Stalina, nie bylibyśmy w stanie wygrać walki z Hitlerem. Postawa ta była niezbędna dla naszej jedności i naszego morale. Byliśmy fanatykami i musieliśmy nimi być. Czy w 1942 r. wierzyłem w każdy szczegół [powyższego] panegiryku, to inna sprawa [...] w listopadzie [...] 1942 r. [...] byliśmy w wyjątkowo trudnej sytuacji, prawdopodobnie posłużyłem się retoryką [...], która miała podnieść na duchu naszych utrudzonych partyzantów. Niezwyciężalność i wszechwiedza Stalina były skutecznym sloganem w obliczu na pozór niezwyciężalnego Hitlera [...] nie całkiem może wierzyłem w każdy z owych przymiotników, którymi obsypywałem Stalina”, lecz „rytualne wynoszenie [go] pod niebiosa było w tych czasach normą" ${ }^{112}$. Podobnie zresztą jak Armii Czerwonej, walczącej nie tylko o wyzwolenie swego kraju, ale i wszystkich innych „spod faszystowskiego jarzma" ${ }^{113}$. Mając jednakże na uwadze również inne, wcześniejsze działania i wypowiedzi Đilasa, nie można pominąć oceny, iż w tych peanach na część Stalina chodziło nie tylko, a być może i nie przede wszystkim o wspomnianą pragmatykę. A także stwierdzenia, że dla Đilasa sowiecki przywódca istotnie był „słońcem, bez którego ziemia niechybnie by zamarzła”, jak metaforycznie napisał jeden z badaczy. Dodając, że Đilasowe wspieranie Stalina było udzielane przez fanatycznego gorliwca, ówcześnie co prawda u władzy, ale jak zwykle niepotrafiącego ujmować politycznej rzeczywistości „w kategoriach politycznych rozwiązań i odpowiedzialnego działania"114.

W 1942 r. fanatyczne, nabożne przywiązanie Đilasa do Stalina i jego polityki było faktem. Ale czy rzeczywiście tylko ono miałoby i mogłoby określać jego postawę? Nic nie wskazuje na to, by fanatyzm istotnie w każdych warunkach wykluczał praktyczne działania jednostek. Wydaje się, że w pewnych sytuacjach Đilas faktycznie wykazywał się pragmatycznym podejściem, zgodnie zresztą z wytycznymi polityki partyjnego kierownictwa. Uważając, że czetnicy Mihailovicia, a więc potencjalni sojusznicy Wielkiej Brytanii, są dla komunistycznych partyzantów najniebezpieczniejsi, Tito postanowił nawiązać kontakty z Niemcami. W rezultacie 11 marca 1943 r. w miejscowości Gornji Vakuf w Bośni doszło do rozmów między przedstawicielami Tity i wojskowych władz niemieckich. Tito chciał rozejmu, zyskania na czasie, koniecznego do rozprawy z czetnikami. Jednym z jego wysłanników był właśnie Đilas. Pytany przez niego, co na takie rozmowy może powiedzieć

111 M. Đilas, Staljin, w: idem, Članci 1941-1946, Beograd 1947, s. 34-37, pierwotnie w „Borbie” (7 XI 1942).

112 Idem, Chrystus i komisarz..., s. 188.

113 Idem, Crvena Armija - spasilac čovječanstva, w: idem, Članci..., s. 72-75, pierwotnie w „Borbie” (15 II 1943).

114 B. Raditsa, op. cit. 
Moskwa, Tito odparł sucho, że Sowieci też „w pierwszym rzędzie myślą o swoich ludziach i o swojej armii”"115. Przekonany taką argumentacją Đilas wykazał się w rozmowach z przedstawicielami Wehrmachtu swoją dawną, „wahabicką" pasją i entuzjazmem. Rozmowy zakończyły się fiaskiem, ale tylko dlatego, że Hitler nie czynił rozróżnienia między czetnikami i partyzantami; ,z buntownikami nie powinno się rozmawiać, buntowników należy wystrzelać"116.

W miarę upływu czasu fanatyczna, stalinowska postawa Đilasa coraz częściej będzie równoważona chłodną kalkulacją, choć całkowicie jeszcze długo nie zniknie. Zacznie on jednakże dostrzegać, że różnice między jugosłowiańskimi komunistami i władzami na Kremlu w konkretnych sprawach nie muszą naruszać wspólnoty ideologicznej; „przecież nasza walka także wzbogaca naukę marksistowsko-leninowską". Jak długo życie przystaje do ideologii, jak długo ideologia wskazuje właściwe kierunki działania, tak długo wykazuje się żywotnością ${ }^{117}$. Niemniej w swoich późniejszych pismach Đilas będzie udowadniał, że wyraźnie zaczynała go nachodzić refleksja, iż faktyczna działalność podejmowana w imię ideologii najczęściej prowadzi do celów sprzecznych z oczekiwaniami. Ta refleksja stanie się jednym z głównych leitmotivów jego powojennej twórczości. Natomiast w czasie zmagań z okupantami na proste pytanie, „jaka siła sprawia, że ludzie się zabijają", zaczynał stopniowo utwierdzać się w przekonaniu, że nie może nią być ani nazistowska, ani „nasza, komunistyczna ideologia”. Jeśli nie one są przyczyną mordów, gwałtów i bestialstwa, to musi za nimi stać jakaś tajemnicza, „niewytłumaczalna siła”. Ideolodzy, politycy, przywódcy państwowi „wyczuwają ją” w ludziach i narodach oraz wyzyskają do urzeczywistniania swoich "podniosłych celów”. W takim ujęciu każda ideologia staje się czymś wtórnym w stosunku do pierwotnych, ludzkich instynktów i namiętności. A także czymś sprzecznym z rzeczywistością, która najczęściej rozwija się w zgodzie właśnie z nimi i własną logiką. $\mathrm{W}$ rezultacie ideologia w niewielkim tylko stopniu może służyć urzeczywistnieniu tych czy innych celów i zamierzeń - społecznych, politycznych, ustrojowych ${ }^{118}$.

$\mathrm{Z}$ biegiem czasu, coraz widoczniejszym końcem II wojny światowej, Đilas miał się umacniać $\mathrm{w}$ tych pesymistycznych przeczuciach. Także pod wpływem pierwszych, bezpośrednich kontaktów z Rosją i władzami na Kremlu. Wiosną 1944 r. jako wysłannik Tity Đilas udał się do Moskwy na „rozmowy ze Stalinem”. Wyjeżdżał „ze wzruszeniem", w czym pewną rolę odgrywały tradycje historyczne, głównie uwielbienie okazywane dawnej, przedrewolucyjnej Rosji w jego rodzimej Czarnogórze. Przecież „nieszczęśni książęta - biskupi udręczonego Czarnogórza [...] odbywali pielgrzymki do Rosji i szukali tam zrozumienia i ocalenia”. Đilas niewątpliwie czuł się spadkobiercą i wyrazicielem tych odczuć i tradycji. Co nie zmienia faktu, że

115 M. Djilas, Wartime..., s. 231.

116 J. Pirjevec, op. cit., s. 178-181; w literaturze polskiej: M.J. Zacharias, Jugosławia w polityce Wielkiej Brytanii..., s. 118-121.

117 M. Djilas, Wartime..., s. 231.

118 M.J. Zacharias, Idee, utopie, rzeczywistość..., s. 58-60. 
chodziło mu przede wszystkim o przywiązanie do Rosji jako państwa rewolucyjnego i komunistycznego, o „powiązania ideologiczne z Moskwą”; o powiązania ruchu, którego przedstawiciele uważali się „za najwierniejszych z jej zwolenników”. Tymczasem sowiecka rzeczywistość widziana z bliska okazywała się niezmiernie rozczarowująca. W Rozmowach ze Stalinem Đilas pisał o ogromnym zacofaniu tego kraju, wyraźnych symptomach szowinizmu, ksenofobii, pogardliwym traktowaniu narodów środkowoeuropejskich, prymitywnych warunkach życia obywateli ZSRS, wywołujących nieprzyjemne uczucia zwłaszcza w konfrontacji z wystawnym, choć prostackim trybem życia Stalina i jego otoczenia. Swoistym stylem spędzania czasu "wolnego", znaczonym „pijaństwami przedstawicieli sowieckich, przybierającymi coraz to bardziej charakter istnych bachanalii”. Podawał także przykłady lekceważącego, a nawet nieprzyjaznego stanowiska władz na Kremlu, prasy sowieckiej, zniekształcającej i pomniejszającej walkę komunistów w Jugosławii, co miało iść w parze, „początkowo ostrożnie, a potem coraz jawniej”, z próbami „podporządkowania propagandy jugosłowiańskiej potrzebom i wzorom sowieckim”. Wszystko to $\mathrm{z}$ wolna i stopniowo miało rozbijać mity i przekonania dotyczące „Kraju Rad”. Identyczne skutki wywoływało zachowanie żołnierzy Armii Czerwonej. Jesienią 1944 r. wkroczyły one na terytorium Jugosławii, siejąc takie samo spustoszenie jak w innych „wyzwolonych” krajach środkowoeuropejskich. Gwałty, napady i rabunki znaczyły ich drogę. W rezultacie wszystkich tych faktów zarówno Đilas, jak i inni przywódcy komunistycznych partyzantów w Jugosławii zaczynali stawać przed dylematami wynikającymi z konieczności skonfrontowania idei z praktyką, coraz bardziej obalającą mityczny wizerunek Josifa Wissarionowicza i jego polityki, a także wyidealizowanej rzeczywistości w Związku Sowieckim ${ }^{119}$.

Đilas wspominał, że jego osobiste rozczarowania wynikały także z sytuacji w Jugosławii w czasie i tuż po klęsce Niemiec. Pisał, że „wszystko potoczyło się inaczej - opacznie”. Uzasadniona skądinąd nacjonalizacja, mająca służyć „zniszczeniu kapitalistycznego sposobu produkcji” i „budowie «bezklasowego społeczeństwa»”, przekształciła się w pospolite grabienie, przywłaszczanie cudzej własności - „willi, bogactwa, nawet własności osobistej”. Đilas dostrzegał w tym zwyrodnienie, upadek moralności, sprzeniewierzenie się sobie i własnym ideałom ${ }^{120}$. Jego spostrzeżenia potwierdził Vladimir Dedijer, pisząc, że „kiedy przed końcem wojny weszliśmy do Belgradu, tempo moralnej erozji było wielkie. Partyzanccy zwierzchnicy przywłaszczyli sobie wille pokonanej burżuazji. [...] Nasza rewolucyjna etyka, którą w mękach wypracowaliśmy w więzieniach Królestwa Jugosławii i na polu walki, bardzo szybko zanikała [...] «nasi towarzysze, robotnicy i chłopi, którzy wiekami umierali z głodu»", obecnie jedli z „z takim apetytem, że cała ich etyka” zanikała „w ich trzewiach”121. Następowało szybkie przejmowanie władzy, czemu

119 Ibidem, s. 61-66.

120 M. Đilas, Razvoj mog političkog mišljenja..., cz. 9.

121 V. Dedijer, Veliki buntownik Milovan Đilas. Prilozi za biografiju, Beograd 1991, s. 294. 
towarzyszyły akty terroru, przeobrażenie „ruchu rewolucyjnego” w dominację biurokracji i władzy państwowej. Powstawał kult Tity porównywalny z tym, jaki posiadał Stalin we własnym państwie. Tito stawał się - pisał Đilas - „małym, bardziej umiarkowanym Stalinem, w małym, nieimperialistycznym kraju”. Jego najbliżsi współpracownicy „chcąc nie chcąc stopniowo i mimowolnie przekształcali się w imitatorów obcej potęgi oraz dworzan własnego, żądnego władzy samodzierżcy”. Zanikało życie umysłowe, „teoretyczne rozważania” były zastępowane „banalnym powtarzaniem" tego, co twórcy marksizmu-leninizmu sami niegdyś stwierdzili, praktyka polityczna zaś sprowadzała się do naśladowania obcych, sowieckich wzorców. Powstawały „świat i życie opanowane przez dogmatyczne szablony”, wymyślone, „nieprzyjazne” stwierdzenia. Đilas dodawał, że chciał wówczas „uzyskać ostateczne uwolnienie od partyjnych obowiązków”, tak by zostać „swobodnym pisarzem, pisarzem komunistą" 122 .

Nasuwa się pytanie, czy i w jakim stopniu powyższe wynurzenia zasługują na zaufanie? Czy Đilas istotnie wykazywał się wówczas takim krytycyzmem? Czy chciał ustąpić i tylko „bieg okoliczności”, a więc „odbudowa i rozbudowa”, szczególnie zaś konflikt z ZSRS z 1948 r. i nalegania towarzyszy, by pozostał „jeszcze jakiś czas aktywny”, udaremniły realizację jego „pragnień i zamierzeń"? ${ }^{123}$ Przecież jego prace i wypowiedzi o tym świadczące powstały później, wiele lat po zakończeniu II wojny światowej. W rezultacie także do Đilasa muszą odnosić się spostrzeżenia, że w naturze ludzkiej leży „pozbywanie się wszystkiego, co zbyteczne” i „zatrzymywanie tylko tego, co w świetle późniejszych wydarzeń okazywało się najważniejsze”. Także dlatego, że "słabą stroną" „natury” jest uleganie nastrojom dostosowującym „minioną rzeczywistość do bieżących potrzeb i przyszłych nadziei"124. Ostatecznie wszystko to sprawia, że postawione wyżej pytania muszą pozostać bez odpowiedzi.

\section{Milovan Đilas - A Politician, Thinker, Analyst of the Communist System. Part 1: A Rebel and Communist}

\section{Abstract}

In the article, Michał Jerzy Zacharias presents the evolution of the political stance, especially the political thought of Milovan Đilas on the so-called 'new class' and the communist system: its origins, character, and inevitable collapse. This evolution concerns the formation, nature, transformations, and unavoidable - in the opinion of the Yugoslav analyst - collapse of this system. The author draws attention to the views and concepts of the 'new class' as depicted by his predecessors, starting with Nikolai Bakunin. He makes the readers aware of the fact that

122 M. Đilas, Razvoj mog političkog mišljenja..., cz. 9.

123 B. Kovačević, op. cit., s. 184.

124 M. Dżilas, Rozmowy ze Stalinem..., s. 9. 
The New Class' author was neither the first nor the only thinker to emphasise the negative role of the new ruling strata that emerged after the revolution and subjugated the whole society. Zacharias also provides facts proving that, according to Đilas, the 'new class', i.e. the party (communist) political bureaucracy, was a completely different phenomenon from the classes of the capitalist system. First of all, due to the power monopoly in every field: political, economic, and ideological. Đilas stresses that in bourgeois societies, individual classes and their emanations, political parties, always had to be content with only a partial share in power and only political. This monopolisation of power in all possible areas by the 'new class' leads Đilas to conclude that the communist system is truly "a power that has become an end in itself". Such an approach is entirely at variance with the theories of Karl Marx, and also others, in practice, all Marxist theoreticians contemporary with the Das Kapital's author. All this, even though Đilas uses Marxist concepts, theoretical categories and Marxist, class-based analysis of economic, social, and political processes. Noteworthy is also his insightful analysis of the collapse of the communist system. Both in his The New Class and later works, he would write that it was the internal contradictions, the existence and operations of the 'new class' that became the fundamental reasons for the collapse of communism - its decay and self-destruction.

\section{Милован Джилас - политик, мыслитель, аналитик коммунистической системы. Ч. 1 Бунтарь и коммунист}

\section{Аннотация}

В представленной статье Михал Ежи Захариас излагает эволюцию политической позиции, прежде всего - политической мысли Милована Джиласа о так называемом новом классе и коммунистической системе. Эта эволюция связана с возникновением, характером, преобразованиями и неизбежным, по мнению югославского аналитика, распадом этой системы. Захариас обращает внимание на взгляды и концепции «нового класса» в изложении его предшественников, начиная с Николая Бакунина. Этим наглядно показывается, что автор Нового класса не был первым и единственным мыслителем, обратившим внимание на негативную роль нового правящего слоя, сформировавшегося после революции и подчинившего себе все общество. Автор статьи представляет также факты, свидетельствующие о том, что, по мнению Джиласа «новый класс», то есть партийная (коммунистическая) политическая бюрократия была явлением совершенно отличным от классов, встречающихся в капиталистической системе. Прежде всего, в силу монополии власти на любом поприще: политическом, экономическом и идеологическом. Джилас подчеркивает, что в буржуазных обществах отдельные классы и их эманации, то есть политические партии, всегда должны были довольствоваться лишь частичным участием во власти, и то лишь политической. Именно монополизация власти «новым классом» на всех возможных поприщах привела Джиласа к выводу, что коммунистическая система - это, в сути, лишь «власть, которая стала самоцелью». Такой подход полностью противоречит теориям Карла Маркса, как и других, на практике всех марксистских теоретиков, современников создателя Капитала. Независимо от того, что Джилас использует марксистские понятия, теоретические категории и марксовый классовый анализ экономических, социальных и политических процессов. Заслуживает внимания и его проницательный анализ краха, распада коммунистической системы. И в Новом классе, и в своих последующих произведениях он будет писать, что именно внутренние противоречия, существование и действия «нового класса» стали основными причинами распада коммунизма - его разложения и самоуничтожения. 


\section{Bibliografia}

\section{Pisma i wypowiedzi Milovana Đilasa}

Anatomy of a Moral. The Political Essays of Milovan Djilas, London 1959.

Chrystus i komisarz, w: Stalin i stalinizm. Rozmowy Georgea Urbana, London 1987.

Članci 1941-1947, Beograd 1947.

Intervju - Milovan Đilas. Ima li boljeg sugovornika od Milovana Đilasa, ako je reč o krahu komunizma?, „Vreme” (2 IX 1991), br. 45, vreme.com/cms/view.php? id=1665176 (dostęp: 20.07.2019).

Land Without Justice. An Autobiography of his Youth, London 1958.

Les accusations injustes et depourvues des principes dirigées contre le PCY, Belgrade [b.d.w.]. Memoirs of a Revolutionary, New York 1973.

Nowa klasa. Analiza systemu komunistycznego, tłum. A. Lisowski, Nowy Jork 1958.

O tridesetogodišnjici Oktobarske revolucije. Referat na svečanoj akademiji Izvršnog odbora Narodnog fronta Jugoslawije, Zagreb 1947.

Pad nove klase. Povest o samorazaranju komunizma, Beograd 1994.

Parts of a Lifetime, New York-London 1975.

Pisma iz zatvora, Beograd 2016.

Početak kraja i početka, „Nova Misao” (1953), 8.

Razvoj mog politickog mišljenja, http:/milovandjilas/Tekstowi/razwoj\%mogpolitickog\%misljenja. pdf (dostęp: 15.06.2014).

Rise and Fall, San Diego-New York-London 1985.

Rozmowy ze Stalinem, Paryż 1962.

Savremene teme, Beograd 1950.

Une societé imparfaite. Le communism désintegré, Paris 1969.

Wartime, New York-London 1977.

\section{Źródła drukowane}

Broz-Tito J., O partiji i ulozi komunista, t. 4: Osvrt na istorijski razwitak KPJ (SKJ) 1919-1940, Beograd 1984.

Đilas A., Đido, w: M. Đilas, Pisma iz zatvora, Beograd 2016, s. 332-357.

Guillaume J., L'Internationale. Documents et souvenirs (1864-1878), t. 1, Paris 1905.

Milovan Đilas 1989 godine: Kako je nastalo samoupravljanje i kako je nestao komunizam, archiwa.nedeljnik.r.s/velike price/portalnews/milovan-dilas-1989-godine-kako-je-nastalosamouprawljanje-i-kako-je-nestalo-komunizam (dostęp: 30.07.2019).

\section{Opracowania}

Babić M., Fenomen dysydenta jugosłowiańskiego. Przypadek Milovana Djilasa, Warszawa 2015. Banac I., With Stalin Against Tito. Communists Splits in Yugoslav Communism, Ithaca-London 1988.

Bierdiajew M., O rosyjskiej rewolucji: Oskarżenia rosyjskiej inteligencji, www.konserwatyzm.pl/ mikolaj-bierdiajew-o-rosyjskiej-rewolucji-oskarzenie-rosyjskiej-inteligencji-cz-i/ (dostęp: 15.11.2016).

Bierdiajew M., Źródła i sens komunizmu rosyjskiego, tłum. i oprac. H. Paprocki, Kąty 2005.

Cemović M., Đilasovi odgovori, Beograd 1997.

Clissold S., The Progress of a Revolutionary, Hounslow-Middlesex 1983. 
Dedijer V., Noviprilozi za biografiju Josipa Broza Tita, t. 2, Rijeka-Zagreb 1982.

Dedijer V., Veliki buntownik Milovan Đilas. Prilozi za biografiju, Beograd 1991.

Furet F., Przeszłość pewnego złudzenia. Esej o idei komunistycznej w XX w., tłum. J. Górnicka-Kalinowska, M. Ochab, Warszawa 1996.

Kalezić V., Ljevica u sukobu s Krležom, Beograd 1990.

Kalezić V., Partijska linija u sećanju Vladimira Bakarića, „Književna reč” (25 XII 1983).

Kisić Kolanović N., Hebrang. Iluzjie i otrežnjenja, Zagreb 1996.

Kołakowski L., Główne nurty marksizmu, t. 1-3, Warszawa 2009.

Kovačević B., Đilas. Heroj-antiheroj-iskazi za istoriju, Podgorica 2006.

Krleža M., Dijalektički antibarbarus, „Pečat” (1939), nr 8-9.

Lasić S., Sukob na književnoj ljevivi 1928-1952, Zagreb 1970.

Leković D., Milovan Đilas i socijalizam. Filozofsko-istorijskra razmatranja, Podgorica 2010.

Milikić Mido M., Ratnim stazama Milovana Đilasa, Beograd 2011.

Pavlićević V., „Lijeve greške” Milovan Đilasa ili partyjski silogizam, Podgorica 2012.

Pavlićević V., Dissident Đilas (Polemike, podsječaja, tumačenja), Podgorica 2016.

Pipes R., Rosja bolszewików, tłum. W. Jeżewski, Warszawa 2005.

Pirjevec J., Tito, tłum. J. Pomorska, J. Sławińska, Warszawa 2018.

Raditsa B., The Idealism of Milovan Djilas, „Commentary” (II 1963), s. 149-152, Commentarymagazine.com/articles/the-idealism-of milovan-djilas (dostęp: 15.07.2019).

Radovčić M., Milovan Đilas u sukobu na književnoj ljevici. Diplomski rad, darhiv.ff.umizg.hr/ id/eprint/2410/2/Dilas\%2520 diplomski.pdf (dostęp: 22.06.2019).

Shatz M.S., Jan Waclaw Machajski. A Radical Critic of the Russian Intelligentsia and Socialism, Pittsburgh (Pa.) 1989.

Stanić V., „Unutrašnji emigrant”: političke ideje Milovana Đilasa 1954-1989, „Poznańskie Studia Slawistyczne" (2014), nr 6.

Sulzberger C.L., Paradise Regained. Memoir of a Rebel, New York-London 1985.

Tomić Đ., Stojaković K., Iz povijesti jugoslovanske ljevice od početka 19. stoljeća do izbijanja drugog svetskog rata. Skića poglava koje ne dostaje, „Perspektive” (2013), nr 7.

Walicki A., O inteligencji, liberalizmach i o Rosji, Kraków 2007.

Walicki A., O Rosji inaczej, Warszawa 2019.

Walicki A., Zarys myśli rosyjskiej. Od oświecenia do renesansu religijno-filozoficznego, Kraków 2005.

Wolkogonow D., Trockij, t. 1, Moskwa 1992.

Zacharias M.J., Idee, utopie, rzeczywistość. Myśl polityczna Milovana Đilasa (1911-1995), Bydgoszcz 2015.

Zacharias M.J., Intelligentsia and the New Class. Political Elites According to Jan Wacław Machajski and Milovan Đilas, „Studia z Dziejów Rosji i Europy Środkowo-Wschodniej” 52 (2017), z. 3 .

Zacharias M.J., Jugosławia w polityce Wielkiej Brytanii 1940-1945, Wrocław 1985.

Zacharias M.J., Komunizm, federacja, nacjonalizmy. System władzy w Jugosławii 1943-1991. Powstanie, przekształcenia, rozkład, Warszawa 2004. 
Michał Jerzy Zacharias, em. prof. zw. UKW w Bydgoszczy. W latach 1990-2007 w Instytucie Historii Polskiej Akademii Nauk. Od 1999 r. związany z Wyższą Szkołą Pedagogiczną w Bydgoszczy, przekształconą w Akademię Bydgoską, a następnie w Uniwersytet Kazimierza Wielkiego. Był pracownikiem Instytutu Nauk Politycznych UKW. Obszar zainteresowań: historia powszechna i Polski XX w., szczególnie polityka międzynarodowa, polska polityka zagraniczna, Jugosławia, elity, ustroje i myśl polityczna tego stulecia (michal.j.zacharias@gmail.com).

Michał Jerzy Zacharias, professor emeritus of Kazimierz Wielki University in Bydgoszcz. In 19902007, employed at the Institute of History of the Polish Academy of Sciences. From 1999 on, associated with the Higher Teacher Education School in Bydgoszcz, which was transformed into the Bydgoszcz Academy and then into the Kazimierz Wielki University. He worked at the Political Science Institute of the University. His areas of interest cover: universal and Polish history of the 20th century, especially international politics, Polish foreign policy, Yugoslavia, elites, regimes and political thought of the 20th century (michal.j.zacharias@gmail.com). 